\title{
Optimization of Cat's Whiskers Tea (Orthosiphon stamineus) Using Supercritical Carbon Dioxide and Selective Chemotherapeutic Potential against Prostate Cancer Cells
}

\author{
Fouad Saleih R. Al-Suede, ${ }^{1}$ Mohamed B. Khadeer Ahamed, ${ }^{1}$ \\ Aman S. Abdul Majid, ${ }^{2}$ Hussin M. Baharetha, ${ }^{1}$ Loiy E. A. Hassan, ${ }^{1}$ Mohd Omar A. Kadir, ${ }^{3}$ \\ Zeyad D. Nassar, ${ }^{4}$ and Amin M. S. Abdul Majid ${ }^{1}$ \\ ${ }^{1}$ EMAN Research and Testing Laboratories, School of Pharmaceutical Sciences, Universiti Sains Malaysia, 11800 Minden, Pulau Pinang, \\ Malaysia \\ ${ }^{2}$ Advanced Medical and Dental Institute (IPPT), Universiti Sains Malaysia, 11800 Minden, Pulau Pinang, Malaysia \\ ${ }^{3}$ School of Industrial Technology, Universiti Sains Malaysia, 11800 Minden, Pulau Pinang, Malaysia \\ ${ }^{4}$ School of Pharmacy, The University of Queensland, 20 Cornwall Street, Woolloongabba, QLD 4102, Australia
}

Correspondence should be addressed to Amin M. S. Abdul Majid; aminmalikshah@gmail.com

Received 6 June 2014; Accepted 29 July 2014; Published 7 September 2014

Academic Editor: K. B. Harikumar

Copyright (C) 2014 Fouad Saleih R. Al-Suede et al. This is an open access article distributed under the Creative Commons Attribution License, which permits unrestricted use, distribution, and reproduction in any medium, provided the original work is properly cited.

\begin{abstract}
Cat's whiskers (Orthosiphon stamineus) leaves extracts were prepared using supercritical $\mathrm{CO}_{2}\left(\mathrm{SC}-\mathrm{CO}_{2}\right)$ with full factorial design to determine the optimum extraction parameters. Nine extracts were obtained by varying pressure, temperature, and time. The extracts were analysed using FTIR, UV-Vis, and GC-MS. Cytotoxicity of the extracts was evaluated on human (colorectal, breast, and prostate) cancer and normal fibroblast cells. Moderate pressure $(31.1 \mathrm{MPa})$ and temperature $\left(60^{\circ} \mathrm{C}\right)$ were recorded as optimum extraction conditions with high yield (1.74\%) of the extract (B2) at 60 min extraction time. The optimized extract (B2) displayed selective cytotoxicity against prostate cancer (PC3) cells $\left(\mathrm{IC}_{50} 28 \mu \mathrm{g} / \mathrm{mL}\right.$ ) and significant antioxidant activity (IC 50 $42.8 \mu \mathrm{g} / \mathrm{mL}$ ). Elevated levels of caspases 3/7 and 9 in B2-treated PC3 cells suggest the induction of apoptosis through nuclear and mitochondrial pathways. Hoechst and rhodamine assays confirmed the nuclear condensation and disruption of mitochondrial membrane potential in the cells. B2 also demonstrated inhibitory effects on motility and colonies of PC3 cells at its subcytotoxic concentrations. It is noteworthy that B2 displayed negligible toxicity against the normal cells. Chemometric analysis revealed high content of essential oils, hydrocarbon, fatty acids, esters, and aromatic sesquiterpenes in B2. This study highlights the therapeutic potentials of $\mathrm{SC}-\mathrm{CO}_{2}$ extract of cat's whiskers in targeting prostate carcinoma.
\end{abstract}

\section{Introduction}

Leaves of Orthosiphon stamineus Benth. (Lamiaceae) have been widely used as herbal tea called "cat's whiskers or Java tea" in Asian and European countries. The herb is widely distributed in Southeast Asian countries, particularly Malaysia, Indonesia, and China. Leaves of the herb have been traditionally used for the treatment of variety of ailments including cancer, arthritis, hypertension, and renal stones [1]. It is reported that the herb has dynamic pharmacological properties including anti-inflammatory, antioxidant, and antibacterial properties [2]. The extracts of O. stamineus have been shown to be exceptionally safe with no signs of toxicity in vivo [3]. Antitumour studies have shown that solvent extract of $O$. stamineus leaves inhibited human colon tumour in nude mouse xenograft model $[4,5]$. Detailed chemical analysis has shown the presence of active principle such as rosmarinic acid, sinensetin, eupatorin, and $3^{\prime}$-hydroxy$5,6,7,4^{\prime}$-tetramethoxyflavone [5]. It is suggested that the in vivo antitumor efficacy of the solvent extracts could be due 
to the collective contribution of antioxidant-rich phytochemicals [4].

When dealing with the extraction of botanical products, the key issues for both researchers and pharmaceutical companies are the effect of the extraction process on the nutritional or active medicinal components, including their toxicity and the residues of solvent. Conventional extraction methods have some disadvantages such as the long extraction time, the inconsistent temperatures that affects the active compounds, and the use of chemical solvents and the residual solvents in the final product. Thus, nowadays supercritical fluid extraction (SFE) is found worthwhile in the extraction of natural products. Supercritical carbon dioxide $\left(\mathrm{SC}-\mathrm{CO}_{2}\right)$ is the best alternative method which employs $\mathrm{CO}_{2}$ as an extraction solvent. It is inexpensive and environment-friendly as it can be recycled. It is nontoxic and safe with no residual solvents in the extract [6]. The additional advantage of this technique is that it uses a low temperature for extraction which helps to prevent sample degradation [7]. Similarly, a number of studies have reported the advantages of SC- $\mathrm{CO}_{2}$ in extraction of active compounds from medicinal herbs [8].

To our knowledge, so far, there have been no reports on the effect of SC- $\mathrm{CO}_{2}$ on extraction yield and cytotoxicity of $O$. stamineus leaves extracts. Thus, in the present work, an attempt was made to optimize the different extraction conditions using supercritical fluid extraction method to obtain the maximum yield of the extract of $O$. stamineus leaves with potent antioxidant activity. The extracts were tested for antiproliferative property against a panel of human cancer cell lines. Further a series of investigations were conducted on prostate cancer cell line to elucidate the mechanism of action. Chemometric analysis of the SC$\mathrm{CO}_{2}$ extracts was studied using UV, FTIR, and GC-MS to correlate the potential biological activity with the chemical composition.

\section{Materials and Methods}

2.1. Plant Material and Reagents. Leaves of O. stamineus were collected from the botanical garden, School of Pharmaceutical Sciences, Universiti Sains Malaysia (USM), in March 2013. The floral characteristics of $O$. stamineus were studied and confirmed by the Senior Botanist Mr. Shanmugan, School of Biological Sciences, USM. The herbarium specimen (Voucher number: 11009) was deposited at the herbarium of School of Biology, Universiti Sains Malaysia. Commercial liquid carbon dioxide gas with purity of $99 \mathrm{~g} \mathrm{~kg}^{-1}$ in a gas cylinder at a temperature below $-5^{\circ} \mathrm{C}$ was supplied locally from Malaysian Oxygen Company, Penang, Malaysia. Analytical GC-grade nhexane, absolute (99.9\%) ethanol (Fisher Scientific, Loughborough, UK) and MTT (3-(4,5-dimethylthiazol-2-yl)-2,5 diphenyl tetrazolium bromide) were purchased from SigmaAldrich, Germany. DMSO (dimethyl sulfoxide) was obtained from Sigma-Aldrich, Germany. All chemicals used were either HPLC or analytical grade. Human caspases 3/7, caspase 8, and caspase 9 FAM FLICA kits and Hoechst 33342 and Rhodamine 123 stains were purchased from Immunochemistry Technologies (Minnesota, USA).
2.2. Cell Culture and Cell Lines. Human colorectal carcinoma (HCT 116), hormone sensitive and invasive breast cancer (MCF-7), hormone resistant breast cancer (MDA-MB-231), prostate carcinoma (PC-3), and human normal fibroblast (CCD-18Co) cell lines were obtained from American Type Culture Collection (ATCC), Rockville, MD, USA. Cells were cultured at $5 \% \mathrm{CO}_{2}$-humidifed atmosphere at $37^{\circ} \mathrm{C}$ in growth medium supplemented with $10 \%$ heat-inactivated fetal bovine serum (HIFBS) and 1\% penicillin/streptomycin (PS). HCT 116 and MCF7 cells were cultured in RPMI-1640 and MEM media, respectively. PC-3 and CCD-18Co cells were cultured in F-12K and MDA-MB-231 cells were grown in DMEM supplemented with 5\% HIFBS and PS.

2.3. Supercritical Carbon Dioxide $\left(\mathrm{SC}-\mathrm{CO}_{2}\right)$ Extraction. The $\mathrm{SC}-\mathrm{CO}_{2}$ extraction was conducted using a supercritical fluid extractor SFX 220 (ISCO, Inc., Lincoln, NE, USA; model SFX 220) with $2 \mathrm{~mL}$ extractor vessel capacity. The flow rates for liquid $\mathrm{CO}_{2}$ were fixed at $1.5 \mathrm{~mL} / \mathrm{min}$. All variables (extraction time, pressure temperature) and $\mathrm{CO}_{2}$ flow rates were adjusted. General factorial design of three variable multilevels was applied with thirty-six runs to investigate the operating parameters that influence the supercritical extraction condition of $O$. stamineus tea leaves to obtain the highest yield. One gram powder of O. stamineus leaves (500 $\mu \mathrm{m}$ in diameter) was placed into the extractor vessel. The extraction was then performed under various experimental conditions in accordance with the full factorial design. The first independent variable studied was extraction pressure $(\mathrm{MPa})$ at three various levels $(20.7,31.1$, and $41.4 \mathrm{MPa})$. The second independent variable was temperature with three levels $\left(40,60\right.$, and $\left.80^{\circ} \mathrm{C}\right)$. Time is the third variable with four levels $(15,30,45$, and $60 \mathrm{~min})$. The yield was recorded at each design point. Extraction was carried out at all the design points and each extraction was run in three replicates. The extracts were collected and weighed to calculate the percentage yield and stored at $-20^{\circ} \mathrm{C}$ until further use.

\subsection{Characterization and Phytochemical Analysis}

2.4.1. FTIR. FTIR spectra were recorded at wavelength range from 4000 to $400 \mathrm{~cm}^{-1}$ using Thermo-Nicolet Nexus 670 spectrometer (Thermo Scientific, USA) equipped with OMNIC application software (Thermo, Electron Corporation, USA).

2.4.2. UV-Vis Spectrophotometry. UV-Vis spectrophotometry was carried out using Lambda25 UV/Vis spectrophotometer system operated with UV WinLab V2.85 software (Perkin Elmer, USA). Samples were prepared in methanol at $100 \mu \mathrm{g} / \mathrm{mL}$ and were scanned at the wavelength range from 500 to $200 \mathrm{~nm}$.

2.4.3. Gas Chromatography-Mass Spectroscopy (GC-MS) Analysis. Quantitative chemical analysis of the $\mathrm{SC}-\mathrm{CO}_{2}$ extracts was carried out using GC-MS with an aim to characterize the compound or group of compounds that might be responsible for the observed proapoptotic activity. 


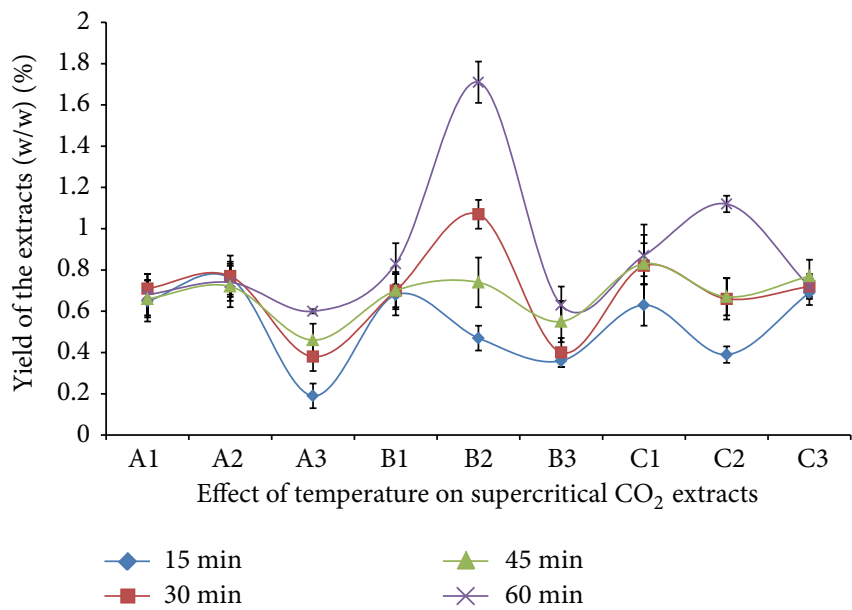

(a)

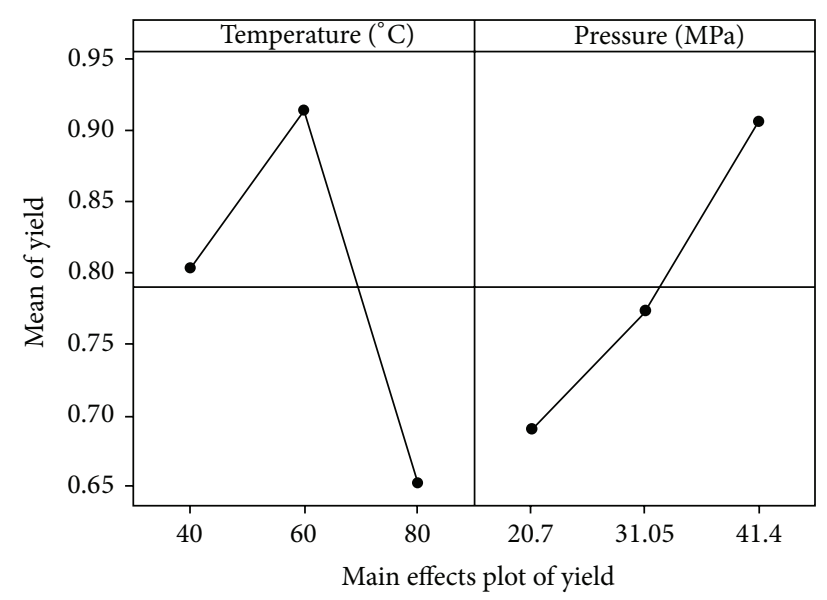

(c)

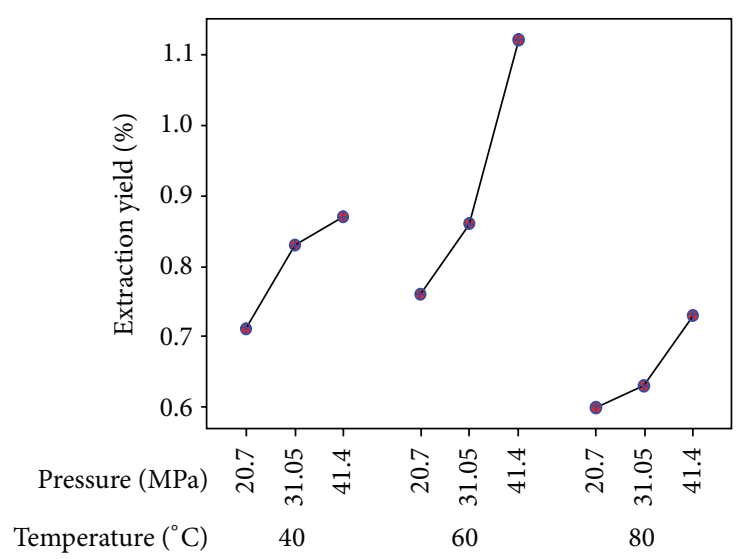

Individual value plot of yield versus temperature $\left({ }^{\circ} \mathrm{C}\right)$, pressure $(\mathrm{MPa})$

(b)

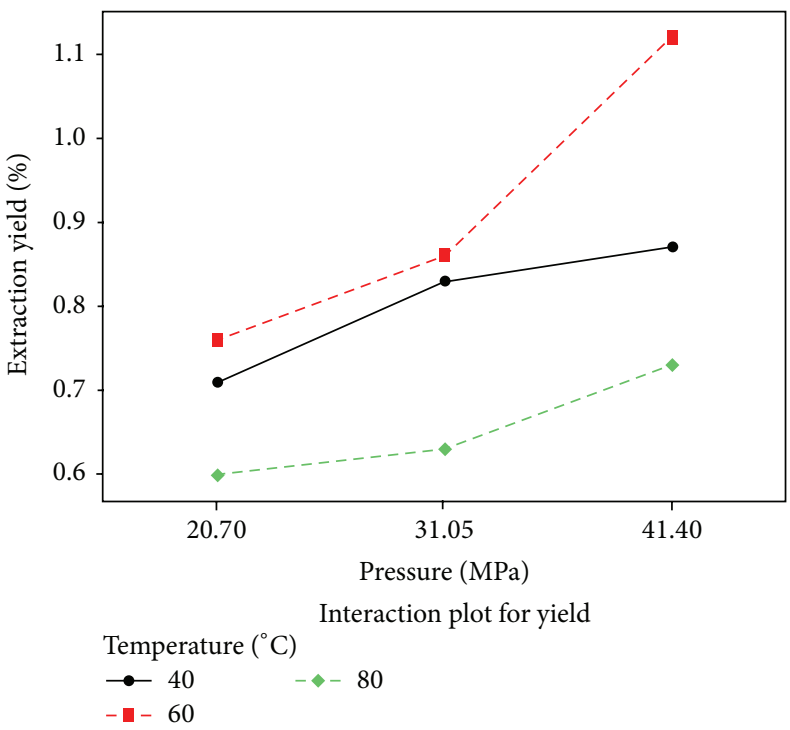

(d)

FIGURE 1: Effect of temperature, pressure, and time on the yield of $\mathrm{SC}-\mathrm{CO}_{2}$ extracts of O. stamineus. (a) Percentage yield ( $\mathrm{g} 100 \mathrm{~g}{ }^{-1}$ ) of the 9 $\mathrm{SC}-\mathrm{CO}_{2}$ extracts of $\mathrm{O}$. stamineus leaves as a function of 4 different time periods $(15,30,45$, and $60 \mathrm{~min})$. The graph shows that $60 \mathrm{~min}$ is the

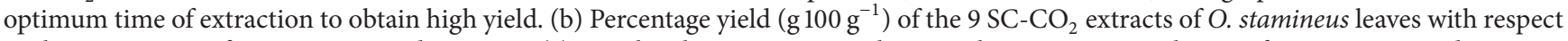
to the interaction of temperature and pressure. (c) Graphical representation showing the opposite correlation of temperature and pressure with the percentage yield. The pressure showed positive influence on the yield whereas the temperature showed negative impact on yield of the extracts. (d) Graphical illustration of the effect of different pressures at fixed temperatures. The figure reveals that as the pressure increased the percentage yield of the extracts also increased at all tested temperatures.

The assay conditions were as follows: HP-5MS capillary column $(30 \mathrm{~m} \times 0.25 \mathrm{~mm}$ ID $\times 0.25 \mu \mathrm{m}$, film thickness); held at $70^{\circ} \mathrm{C}$ for $2 \mathrm{~min}$, raised to $285^{\circ} \mathrm{C}$ at a rate of $20^{\circ} \mathrm{C} /$ minute, and held for $20 \mathrm{~min} ; 285^{\circ} \mathrm{C}$ for MSD transfer line heater; carrier helium at a flow rate of $1.2 \mathrm{~mL} /$ minute; $2: 1$ split ratio. $1 \mu \mathrm{L}$ solution of the extract in chloroform $(10 \mathrm{mg} / \mathrm{mL})$ was injected automatically. Scan parameter low mass: 35 and higher mass: 550. The constituents were identified by comparison with standards using NIST 02. A total ion chromatogram (TIC) was used to compute the percentage of the identified constitutes.

\subsection{Assessment of Antioxidant Activities}

2.5.1. DPPH Radical Scavenging Activity. DPPH (1,1diphenyl-2-picrylhydrazyl) assay [9] was carried out to evaluate the scavenging activity of $\mathrm{SC}-\mathrm{CO}_{2}$ extracts. 
TABle 1: Percentage yield of the extracts obtained from Orthosiphon stamineus tea leaves using $\mathrm{SC}_{-} \mathrm{CO}_{2}$ in relation to time interval, temperature, and pressure.

\begin{tabular}{|c|c|c|c|c|c|c|c|}
\hline \multirow{2}{*}{$\begin{array}{l}\text { Sample } \\
\text { code }^{n}\end{array}$} & \multirow{2}{*}{$\begin{array}{c}\text { Temperature } \\
\left({ }^{\circ} \mathrm{C}\right)\end{array}$} & \multirow{2}{*}{$\begin{array}{c}\text { Pressure } \\
(\mathrm{MPa})\end{array}$} & \multicolumn{4}{|c|}{ Percentage yield $(\mathrm{g} / 100 \mathrm{~g})$ in the extraction time intervals } & \multirow{2}{*}{$\begin{array}{c}\text { Correlation } \\
R^{2} \text { value }\end{array}$} \\
\hline & & & $15 \mathrm{~min}$ & $30 \mathrm{~min}$ & $45 \mathrm{~min}$ & $60 \mathrm{~min}$ & \\
\hline $\mathrm{A} 1$ & 40 & 20.7 & $0.55 \pm 0.1$ & $0.66 \pm 0.07$ & $0.71 \pm 0.07$ & $0.66 \pm 0.09$ & 0.92 \\
\hline $\mathrm{A} 2$ & 60 & 20.7 & $0.42 \pm 0.08^{*}$ & $0.57 \pm 0.1$ & $0.68 \pm 0.1$ & $0.76 \pm 0.1^{*}$ & 0.79 \\
\hline A3 & 80 & 20.7 & $0.38 \pm 0.06$ & $0.42 \pm 0.07$ & $0.46 \pm 0.07$ & $0.46 \pm 0.08$ & 0.66 \\
\hline B1 & 40 & 31.1 & $0.48 \pm 0.1$ & $0.67 \pm 0.09$ & $0.70 \pm 0.09$ & $0.70 \pm 0.08$ & 0.95 \\
\hline B2 & 60 & 31.1 & $0.47 \pm 0.06$ & $1.07 \pm 0.07^{*}$ & $1.07 \pm 0.07^{*}$ & $1.74 \pm 0.12^{*}$ & 0.97 \\
\hline B3 & 80 & 31.1 & $0.36 \pm 0.03$ & $0.40 \pm 0.07$ & $0.40 \pm 0.07$ & $0.55 \pm 0.1$ & 0.89 \\
\hline $\mathrm{C} 1$ & 40 & 41.4 & $0.33 \pm 0.1$ & $0.74 \pm 0.2$ & $0.82 \pm 0.2^{*}$ & $0.87 \pm 0.1^{*}$ & 0.96 \\
\hline $\mathrm{C} 2$ & 60 & 41.4 & $0.32 \pm 0.04$ & $0.72 \pm 0.1$ & $0.66 \pm 0.1$ & $0.67 \pm 0.09$ & 0.93 \\
\hline C3 & 80 & 41.4 & $0.29 \pm 0.06$ & $0.66 \pm 0.05$ & $0.62 \pm 0.05$ & $0.64 \pm 0.08$ & 0.77 \\
\hline
\end{tabular}

Results are presented as mean $\pm \mathrm{SD}(n=3) ;{ }^{*} P<0.05$.

2.5.2. ABTS Assay. Free radical scavenging capability of the extracts was assessed using ABTS assay following the method described by Khadeer Ahamed and coworkers [9].

\subsection{In Vitro Anticancer Studies}

2.6.1. Antiproliferation MTT Assay. MTT assay [10] was performed to assess the cytotoxicity of the SFE extracts on various cancer cell lines (HCT 116, MCF 7, PC-3, and MDAMB-231). Human colonic fibroblast (CCD-18Co) was used as the model cell line for normal cell. The assay plates were read using Tecan microplate reader (Infinite M 200 PRO) at $570 \mathrm{~nm}$ absorbance. DMSO $(0.1 \%)$ was used as a negative control.

2.6.2. Cell Migration Assay. For cell migration assay [11], PC3 cells were seeded and incubated for $48 \mathrm{~h}$ to achieve fully confluent (90-100\%) monolayer.

2.6.3. Colony Formation Assay. Effect of B2 on clonogenicity of PC3 cells was investigated by colony formation assay [12]. The anticlonogenicity of the B2 was estimated in the form of percentage of plating efficiency $(\mathrm{PE} \%)$ and percentage of surviving fraction (SF\%).

2.6.4. Determination of Nuclear Condensation by Hoechst 33342 Stain. Effect of B2 on nuclear chromatin condensation in PC3 cells was quantified by fluorescence microscopy using Hoechst 33258 stain [13].

2.6.5. Detection of Mitochondrial Membrane Potential by Rhodamine 123 Stain. Detection of the changes in mitochondrial membrane potential in PC3 cells treated with B2 was assessed by the retention of rhodamine 123 [14].

2.6.6. Caspase Inhibition Assay. The activity of caspases 3/7, caspase 8, and caspase 9 in PC3 cells treated with B2 was detected using the carboxyfluorescein FLICA apoptosis detection kit [15] following the manufacturer's instructions
(Immunochemistry Technologies, LLC). The percent of caspase induction (CI) was calculated.

2.7. Statistical Analysis. All the results were subjected to ANOVA tests. The responses, the yields, the antioxidant activity, and the proliferative activity of the $\mathrm{SC}-\mathrm{CO}_{2}$ extractions were compared at 5\% significance level. The statistical analysis was conducted using Minitab 16 software (Minitab Inc., State College, PA, USA).

\section{Results}

3.1. Effect of $\mathrm{SC}-\mathrm{CO}_{2}$ Extraction Conditions on O. stamineus Extracts. Effects of extract time, temperature, and pressure were studied on the yield and biological activity of the extracts. Cumulative percentage yield of $\mathrm{SC}-\mathrm{CO}_{2}$ extracts of $O$. stamineus leaves was calculated at intervals of $15 \mathrm{~min}$. The percentage yield increased significantly with increasing extraction time $(P<0.05)$. The results indicate that $60 \mathrm{~min}$ is the optimum extraction time for maximum yield of the extract of O. stamineus leaves by SC-CO $\mathrm{CO}_{2}$ (Figure 1(a)).

Cumulative percentage yield of the extracts was estimated at intervals of $20^{\circ} \mathrm{C}$ and approximate $10 \mathrm{MPa}$ pressure. Figure 1(b) shows the interaction between temperature and pressure. The extraction temperature showed a negative correlation with the percentage yield at 40,60 , and $80^{\circ} \mathrm{C}$ with decreasing order of $R^{2}$, respectively, whereas the extraction pressure showed significantly $(P<0.05)$ positive correlation with the percentage yield at 20.7, 31.1, and 41.4 MPa with $R^{2} 0.92,0.95$, and 0.96 , respectively (Table 1 ). Figure $1(\mathrm{c})$ shows the behavior of two factors (pressure and temperature) separately and their effect on the extraction yield. It can be seen that the two factors have significant effect on the extraction yield. The results of ANOVA analysis exhibited that the effect of these parameters was significant on yield of extraction $P<0.05$.

The results showed that the pressure increment has enhanced the extraction yield at all tested temperatures (Figure $1(\mathrm{~d})$ ). At a fixed extraction temperature of $40^{\circ} \mathrm{C}$, increasing the pressure from 20.7 to $41.4 \mathrm{MPa}$ has increased 
TABLE 2: Transmittance bands correlated to the corresponding wave numbers representing the functional organic groups present in the SC$\mathrm{CO}_{2}$ extracts of Orthosiphon stamineus.

\begin{tabular}{lcc}
\hline Vibrational frequency $\left(\mathrm{cm}^{-1}\right)$ & Samples & Corresponding organic groups \\
\hline $3600-3200$ (broad) & A3, B3, and C3 & O-H stretching \\
$2950-2800$ & All nine samples & C-H stretching \\
$1780-1720$ (sharp) & All nine samples & C=O stretching \\
$1660-1650$ (weak) & C1, C2, B3 and C3 & C=C stretching \\
$1610-1600$ (Sharp) & C1, A2, C2, A3, B3 and C3 & NO ${ }_{2}-$ stretching \\
$1480-1460$ & All nine samples & C-H bending (deformation) \\
$1385-1370$ & All nine samples & C-C, C-H, O-H and C-O bending \\
$1240-1160$ & All nine samples except B2 $-\mathrm{C}, \mathrm{C}-\mathrm{O}, \mathrm{C}-\mathrm{N}$ stretching \\
$1100-1090$ & All nine samples except B2 & $\mathrm{C}-\mathrm{C}, \mathrm{C}-\mathrm{O}, \mathrm{C}-\mathrm{N}$ stretching \\
$1050-1045$ & All nine samples except A1 & $\mathrm{C}-\mathrm{C}, \mathrm{C}-\mathrm{O}, \mathrm{C}-\mathrm{N}$ stretching \\
$960-900$ & All nine samples & $\mathrm{C}-\mathrm{H}$ bending \\
$710-725$ & All nine samples & $\mathrm{C}-\mathrm{H}$ bending \\
\hline
\end{tabular}

the extraction yield from 0.71 to $0.87 \%$, respectively. However, it was found that the extraction rate was enhanced $47 \%$ at extraction temperature of $60^{\circ} \mathrm{C}$. Figure $1(\mathrm{~d})$ depicts that the extraction yield increased significantly from 0.76 to $1.74 \%$ with increasing pressure from 20.7 to $41.4 \mathrm{MPa}$, respectively. Likewise, at a fixed extraction temperature of $80^{\circ} \mathrm{C}$, the extraction yield increased from $0.6 \%$ to 0.73 by increasing the pressure from 20.7 to $41.4 \mathrm{MPa}$, respectively. However, operating extraction pressure of $20.7 \mathrm{MPa}$ was not very beneficial for the extraction yield. As at this extraction pressure the extraction rate at temperature of $40^{\circ} \mathrm{C}$ was $22.5 \%$, which then increased to $47 \%$ at extraction temperature of $60^{\circ} \mathrm{C}$ and then abruptly dropped to $21.6 \%$ at temperature of $80^{\circ} \mathrm{C}$. Altogether, the highest extracted yield was $1.74 \%$ (B2 extract) which was obtained at extraction pressure of 31.1 MPa, using extraction temperature of $60^{\circ} \mathrm{C}$, during a period of $60 \mathrm{~min}$ as shown in Table 1.

\subsection{Phytochemical Study of the Extracts}

3.2.1. FTIR Analysis. FTIR spectra of the extracts obtained at $60 \mathrm{~min}$ are shown in Figures 2(a)-2(c). Table 2 depicts the related functional groups of transmittance bands of the corresponding wavelengths [16].

3.2.2. UV-Vis Spectrophotometry. The UV spectra for the extracts A1, B1, and C1 (Figure 2(d)) displayed strong absorption bands at $\lambda_{\max } 228-232 \mathrm{~nm}$, the characteristic feature for a conjugated double bond, whereas the other extracts showed feeble absorption around this region (Figures 2(e) and 2(f)). Spectrum of the extract A3 showed that the extract lacks the $\pi$-electrons of a double bond or a benzene ring shifts. Further the UV spectra of all extracts, except A1 and A3, showed obvious bands at $\lambda_{\max } 328,279,213,337,272,205,332,273$, and $228 \mathrm{~nm}$.

3.3. Antioxidant Activity of the $\mathrm{SC}-\mathrm{CO}_{2}$ Extracts of $\mathrm{O}$. stamineus Leaves. DPPH and ABTS radicals scavenging activity is presented in terms of the $\mathrm{IC}_{50}$ in Table 3.
It was found that the extracts produced at moderate temperatures and higher pressure (B2 and C2) showed significant antioxidant activity compared to the other extracts. The extract $\mathrm{C} 2$ produced at $60^{\circ} \mathrm{C}$ and $41.4 \mathrm{MPa}$ showed significant $(P<0.01)$ DPPH quenching activity $\left(\mathrm{IC}_{50}=56.1 \mu \mathrm{g} / \mathrm{mL}\right)$. However, the extract $\mathrm{B} 2\left(60^{\circ} \mathrm{C}\right.$ and $\left.31.1 \mathrm{MPa}\right)$ demonstrated more pronounced antioxidant activity than the other tested extracts. The $\mathrm{IC}_{50}$ values of $\mathrm{B} 2$ were 91.7 and $42.8 \mu \mathrm{g} / \mathrm{mL}$ for ABT and DPPH, respectively $(P<0.05)$.

3.4. Antiproliferative Activity of $\mathrm{SC}-\mathrm{CO}_{2}$ Extracts of $\mathrm{O}$. stamineus Leaves. Antiproliferative effect of different SC$\mathrm{CO}_{2}$ extracts of $\mathrm{O}$. stamineus on various human cell lines was tested using MTT assay. Similar to the antioxidant activities, significant $(P<0.01)$ antiproliferative activities have been shown from the extracts obtained under medium and high pressures. The $\mathrm{IC}_{50}$ values of the SFE extracts of $O$. stamineus on various human cell lines are shown in Table 4. The extracts (B2, C1, C2, and C3) prepared at high pressures demonstrated considerable cytotoxic activity against PC3 cell line. The $\mathrm{IC}_{50}$ values of $\mathrm{C} 1, \mathrm{C} 2$, and $\mathrm{C} 3$ were 79,78 , and $73 \mu \mathrm{g} / \mathrm{mL}$, respectively, on PC3 cells. However, among all the extracts, B2 displayed more pronounced antiproliferative effect against PC3 with $\mathrm{IC}_{50} 28 \mu \mathrm{g} / \mathrm{mL}$. In addition, $\mathrm{B} 2$ and $\mathrm{C} 1$ exhibited significant $(P<0.05)$ antiproliferative effect against breast (MDA-MB-231) cell line with $\mathrm{IC}_{50} 57.8$ and $53 \mu \mathrm{g} / \mathrm{mL}$, respectively (Table 3 ). Figure 3 shows the dose-dependent antiproliferative effects of B2, C1, C2, and C3 on MCF7 (Figure 3(a)), MDA-MB-231 (Figure 3(b)), PC-3 (Figure 3(c)), and HCT 116 (Figure 3(d)) cell lines. Figure 4 shows that the photomicrographic images of the treated PC3 and MDA-MB231 cells presented clear evidence of significant cytotoxicity of the extracts, as the vehicle (0.1\% DMSO) treated cells displayed a compact monolayer of aggressively growing cancer cells with prominent nuclei and intact cell membrane, whereas the images taken form the extracts treated group showed a drastic reduction in the number of cells because of the antiproliferative activity of the extracts. In addition, the extracts severely affected the pseudopodial projections of the cells which rendered the cells non-adherent and become 


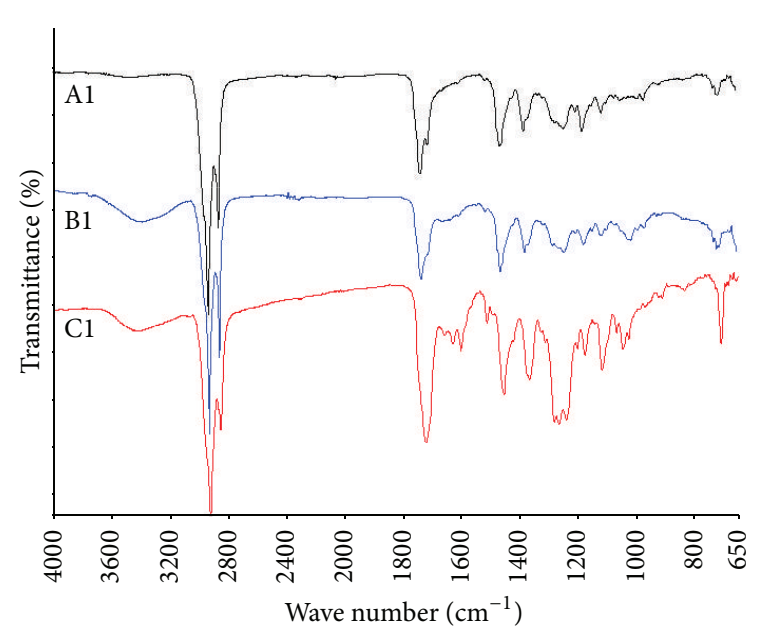

(a)

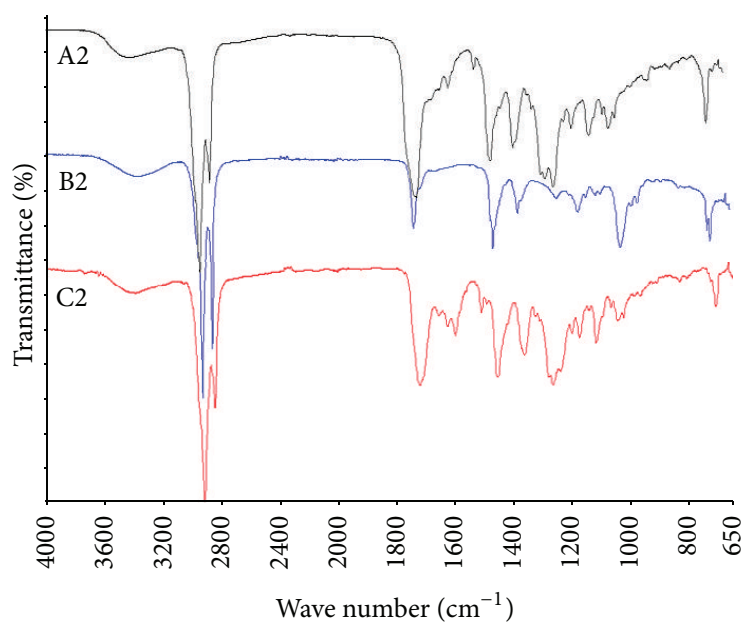

(b)



(c)

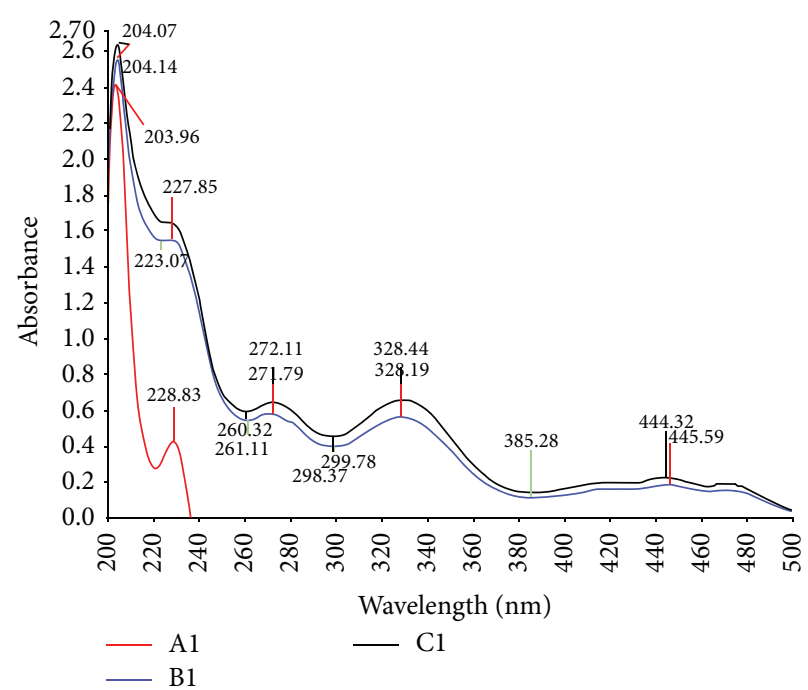

(d)

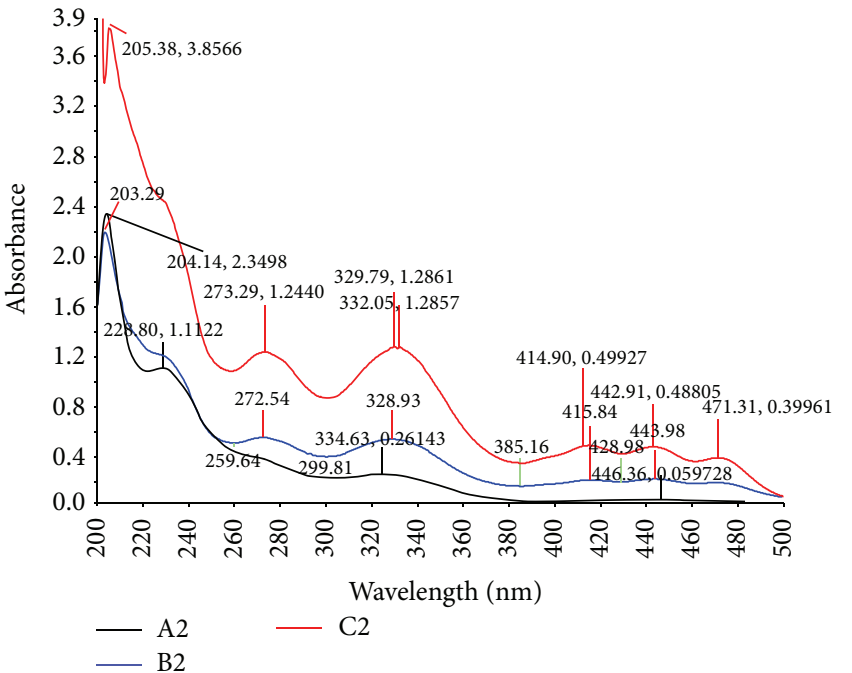

(e)

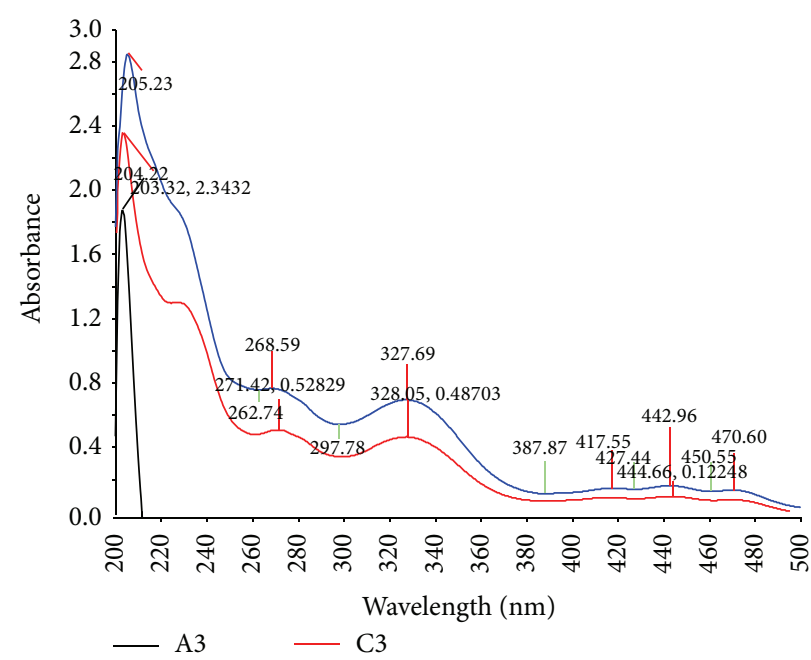

(f)

FIGURE 2: FTIR and UV-Vis spectra of the $9 \mathrm{SC}-\mathrm{CO}_{2}$ extracts of $\mathrm{O}$. stamineus. (a) The extracts $\mathrm{A} 1, \mathrm{~B} 1$, and $\mathrm{C} 1$ ( $\left.40^{\circ} \mathrm{C}\right)$. (b) The extracts $\mathrm{A} 2$, $\mathrm{B} 2$, and $\mathrm{C} 2\left(60^{\circ} \mathrm{C}\right)$. (c) The extracts $\mathrm{A} 3, \mathrm{~B} 3$, and $\mathrm{C} 3\left(80^{\circ} \mathrm{C}\right)$. (d) The extracts $\mathrm{A} 1, \mathrm{~B} 1$, and $\mathrm{C} 1\left(40^{\circ} \mathrm{C}\right)$. (e) The extracts $\mathrm{A} 2, \mathrm{~B} 2$, and $\mathrm{C} 2\left(60^{\circ} \mathrm{C}\right) .(\mathrm{f}) \mathrm{The}$ extracts $\mathrm{A} 3, \mathrm{~B} 3$, and $\mathrm{C} 3\left(80^{\circ} \mathrm{C}\right)$. 


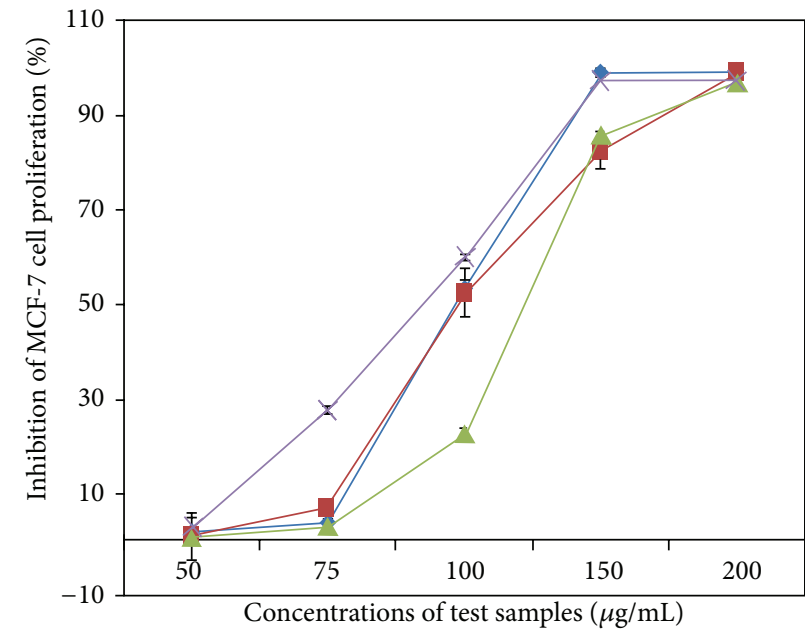

(a)

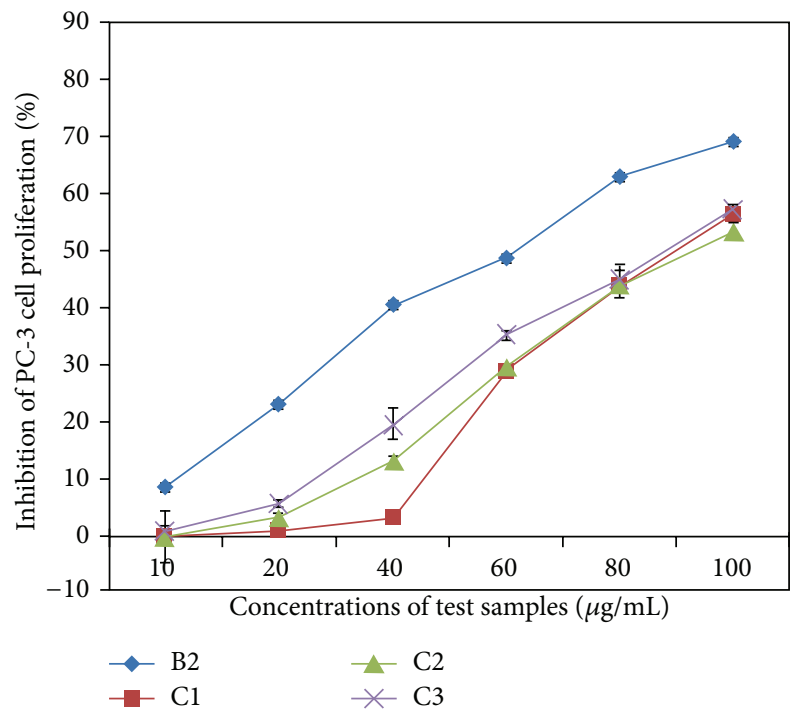

(c)

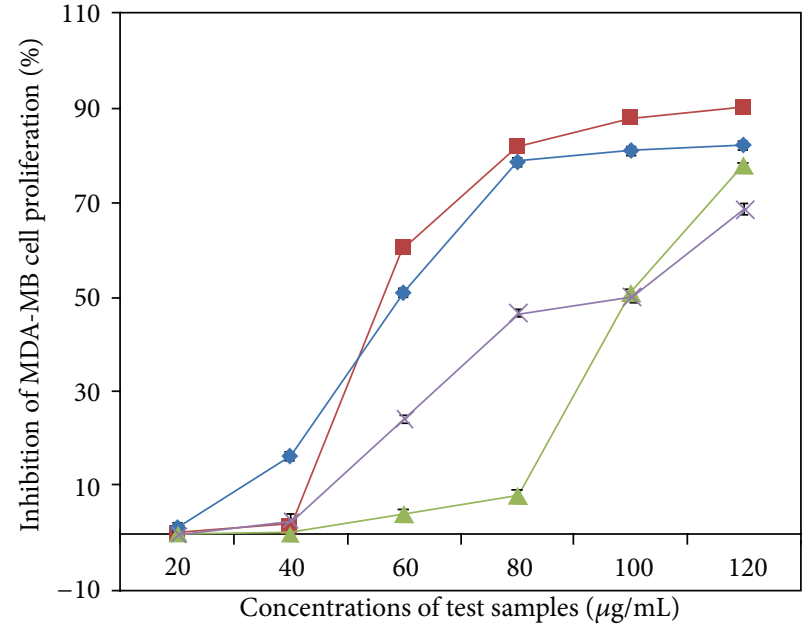

(b)

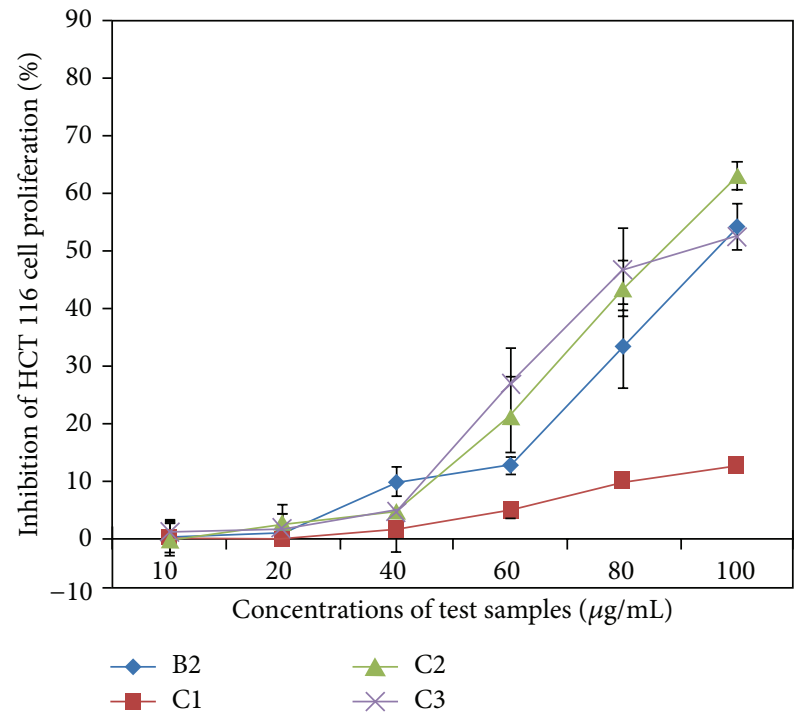

(d)

Figure 3: Dose dependent antiproliferative effect of $\mathrm{SC}-\mathrm{CO}_{2}$ extracts of O. stamineus. (a) The antiproliferative effect of B2, $\mathrm{C} 1, \mathrm{C} 2$, and C3 on estrogen-dependent human breast cancer (MCF7) cells. (b) The antiproliferative effect of B2, C1, C2, and C3 on estrogen-independent human breast cancer (MDA-MB 231) cells. (c) The antiproliferative effect of B2, C1, C2, and C3 on human prostate cancer (PC-3) cells. (d) The antiproliferative effect of B2, C1, C2, and C3 on human colorectal carcinoma (HCT 116) cells.

TABLE 3: Antioxidant activities of the extracts of O. stamineus leaves obtained by supercritical $\mathrm{CO}_{2}$.

\begin{tabular}{lcccccccrrr}
\hline Assays $^{\mathrm{a}}$ & \multicolumn{1}{c}{} & \multicolumn{9}{c}{$\mathrm{IC}_{50}$ values $^{\mathrm{d}}$ of the samples in $\mu \mathrm{g} / \mathrm{mL}$} \\
& $\mathrm{A} 1$ & $\mathrm{~A} 2$ & $\mathrm{~A} 3$ & $\mathrm{~B} 1$ & $\mathrm{~B} 2$ & $\mathrm{~B} 3$ & $\mathrm{C} 1$ & $\mathrm{C} 2$ & $\mathrm{C} 3$ & $\mathrm{AA}$ \\
\hline $\mathrm{ABTS}^{\mathrm{b}}$ & $\mathrm{ND}$ & 1150 & $\mathrm{ND}$ & $\mathrm{ND}$ & $91.7^{*}$ & $\mathrm{ND}$ & 218 & $\mathrm{ND}$ & 117 & $6.5^{* *}$ \\
DPPH $^{\mathrm{c}}$ & $>200$ & $>200$ & $>200$ & 136 & $42.8^{*}$ & 164 & 168 & $56.1^{* *}$ & 198 & $5.8^{* *}$ \\
\hline
\end{tabular}

${ }^{\mathrm{a}}$ Microtiter 96-well plate was used to assess the concentrations $(12.5,25,50,100$, and $200 \mu \mathrm{g} / \mathrm{mL})$ of test samples. Methanol was used as blank. ABTS or DPPH was used as negative control. Ascorbic acid (AA) was used as reference standard.

${ }^{\mathrm{b}}$ Absorbance for ABTS was measured at $734 \mathrm{~nm}$.

${ }^{c}$ Absorbance for DPPH was measured at $517 \mathrm{~nm}$.

${ }^{\mathrm{d}}$ Using linear regression curves the median inhibitory concentrations $\left(\mathrm{IC}_{50}\right)$ were calculated. The results are expressed as mean $\pm \mathrm{SD}(n=6) ;{ }^{*} P<0.05 ;{ }^{* *} P<$ 0.01 . 

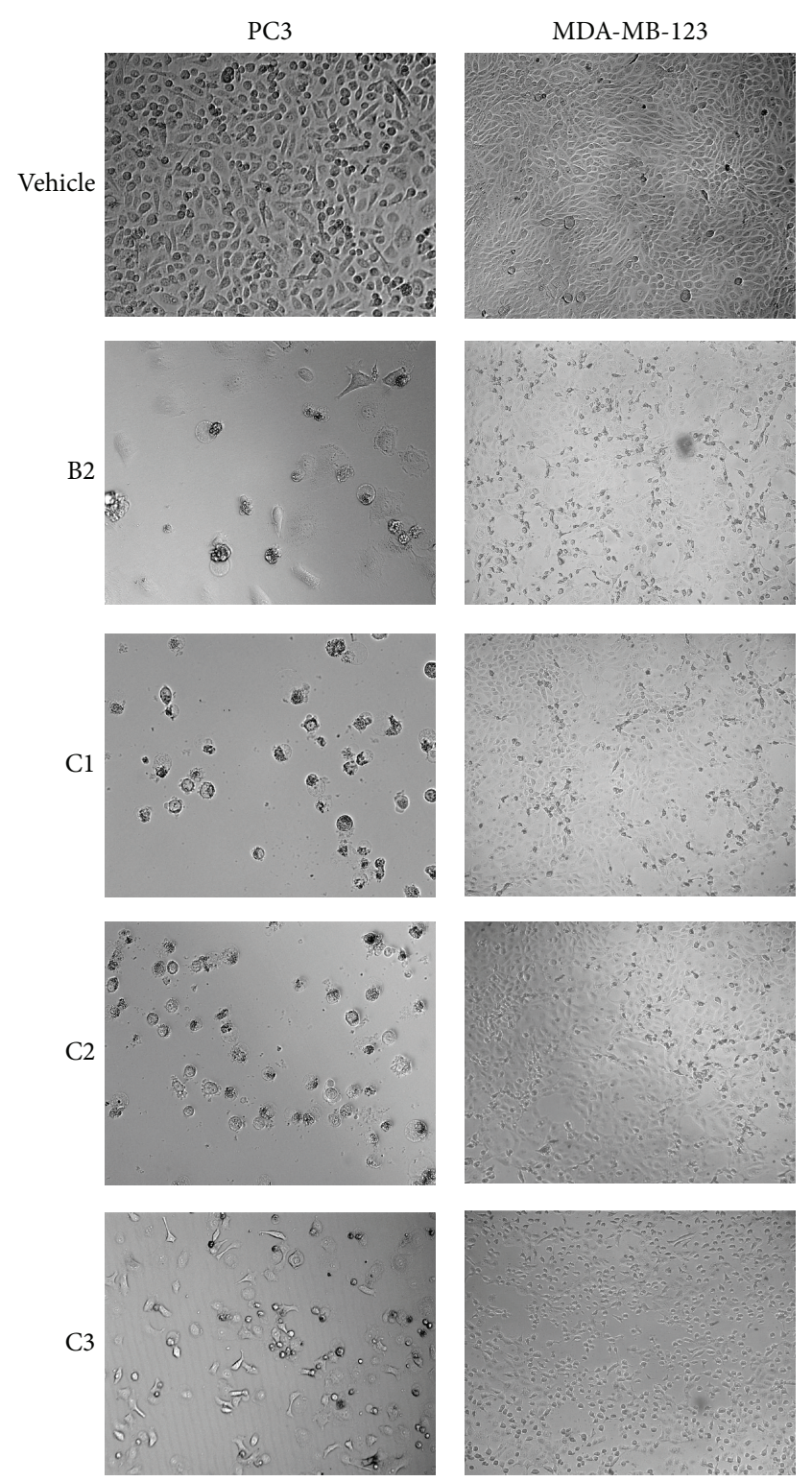

FIGURE 4: Effect of cytotoxicity of SC- $\mathrm{CO}_{2}$ extracts of $\mathrm{O}$. stamineus. Photomicrographic images of PC3 and MDA-MB-231 cells taken under an EVOS f1 digital microscope at 20x magnification after 48 hours of treatment with the B2. The vehicle ( $0.1 \%$ DMSO) treated cells showed fully confluent growth with compact layer of highly proliferating HCT 116 cells. The cells displayed well established pseudopodial cellular projections with prominent nuclei, whereas the extracts (B2, C1, C2, and C3) treated cells demonstrated remarkable inhibitory effect on proliferation of both cell types. The pictures revealed that the population of cells reduced drastically within the 48 hours of treatment. In addition, the extracts induced noticeably morphological changes in the cells.

round shaped. Interestingly, all the extracts studied showed either mild or negligible cytotoxicity towards the CCD-18Co cell line which was used as a model cell line for the normal human cells.

Overall result of cytotoxic test on the human cancer cell lines displayed that the extract B2 demonstrated potent
TABLE 4: Antiproliferative properties of the extracts of O. stamineus leaves obtained by supercritical $\mathrm{CO}_{2}$.

\begin{tabular}{lccccc}
\hline \multirow{2}{*}{ Samples $^{\mathrm{a}}$} & \multicolumn{5}{c}{$\mathrm{IC}_{50} \mu \mathrm{g} / \mathrm{mL}$} \\
& MCF-7 & MDA-MB & HCT116 & PC3 & CCD-18 Co \\
\hline A1 & $>200$ & $>200$ & $>200$ & $>200$ & $>200$ \\
A2 & $>200$ & $>200$ & $>200$ & $>200$ & $>200$ \\
A3 & $>200$ & $>200$ & $>200$ & $>200$ & $>200$ \\
B1 & $>200$ & $>200$ & $>200$ & 84 & $>200$ \\
B2 & 100 & $57.8^{*}$ & 90 & $28^{*}$ & 93.08 \\
B3 & $>200$ & $>200$ & $>200$ & $>200$ & $>200$ \\
C1 & 104 & $53^{*}$ & NA & $79^{*}$ & 94.5 \\
C2 & 125 & 101 & $78^{*}$ & $78^{*}$ & 91.6 \\
C3 & 92 & 90 & 80 & $73^{*}$ & 127 \\
5FU & - & - & $4.6^{* *}$ & - & - \\
Tamoxifen & $9.5^{* *}$ & - & - & - & - \\
Betulinic acid & - & $2.1^{* *}$ & $8.4^{* *}$ & $4.4^{* *}$ & $12.9^{* *}$ \\
\hline
\end{tabular}

ND: not detected.

${ }^{a}$ The test for each extract was performed in triplicate and the results are presented as a mean percent inhibition \pm SD. Each experiment was repeated three times $(n=3) ;{ }^{*} P<0.05 ;{ }^{* *} P<0.01$.

cytotoxicity selectively towards the PC3 cell line as the $\mathrm{IC}_{50}$ obtained is much lower than that of other cell lines. Therefore, in the present study, PC3 cell line is selected to study the effect of B2 on the motility, clonogenicity, morphological modifications, nuclear condensation, mitochondrial membrane potential, and induction of caspases in PC3 cells.

3.5. Inhibitory Effect of B2 on Migration and Clonogenicity of PC3 Cells. B2 demonstrated dose- and time-dependent inhibitory effect on migration of PC3 cells. B2 displayed significant inhibition in cell motility (Figure 5(a)) at the concentration lower than its $\mathrm{IC}_{50}$ on PC3 cells. The percentage of wound closure calculated after $12 \mathrm{~h}$ was $29 \pm 3,18 \pm 5$, and $5 \pm 3 \%$ at 12,25 , and $50 \mu \mathrm{g} / \mathrm{mL}(P<0.05)$. Even after $12 \mathrm{~h}$ the percentage of wound closure was significantly inhibited by B2. Figure 5(b) graphically illustrates the potent inhibitory effect of B2 on motility of PC 3 cells which can be compared with the standard reference, betulinic acid.

The dose-dependent inhibitory effect of B2 on colony formation of PC3 cells was depicted in Figure 5(c). Percentage of plating efficiency (PE) in vehicle (0.1\% DMSO) treated cells was $58 \pm 2 \%$ which was drastically decreased to $30 \pm 4$, $28 \pm 2$, and $23 \pm 3 \%$ upon treatment with B2 at 12,25 , and $50 \mu \mathrm{g} / \mathrm{mL}$, respectively (Figure $5(\mathrm{~d})$ ). The surviving fraction (SF) was determined to be $58 \pm 3,53 \pm 3$, and $45 \pm 2 \%$ after B2 treatment at the concentrations 12,25 , and $50 \mu \mathrm{g} / \mathrm{mL}$, respectively (Figure 5(e)). These results can be compared with the standard reference, betulinic acid.

3.6. B2 Induces Morphological Modifications and Nuclear Condensation in PC3 Cells. In the present study, the effect of B2 on PC3 cells was tested to study morphological modifications and nuclear condensation using Hoechst 33342 stain. Microscopic examination revealed that B2 induced the typical apoptotic morphological changes in PC3 cells in 

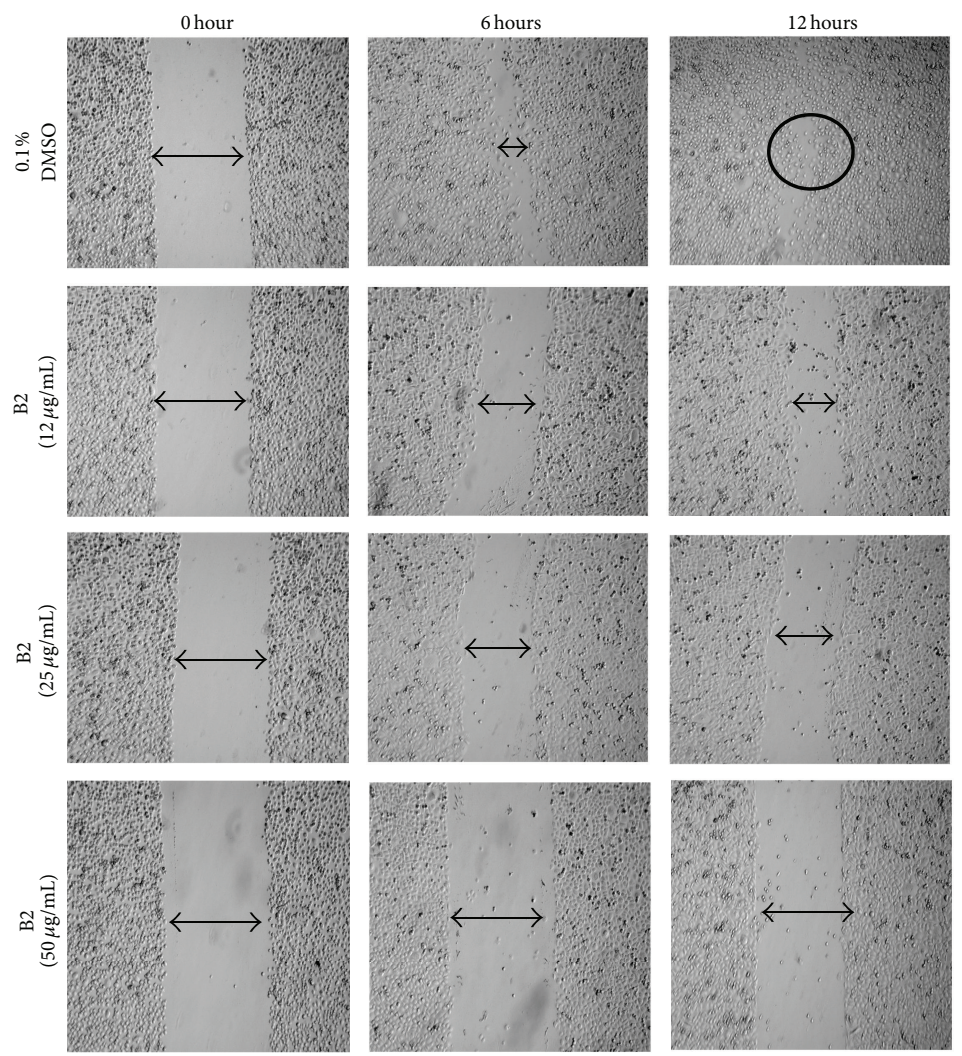

(a)

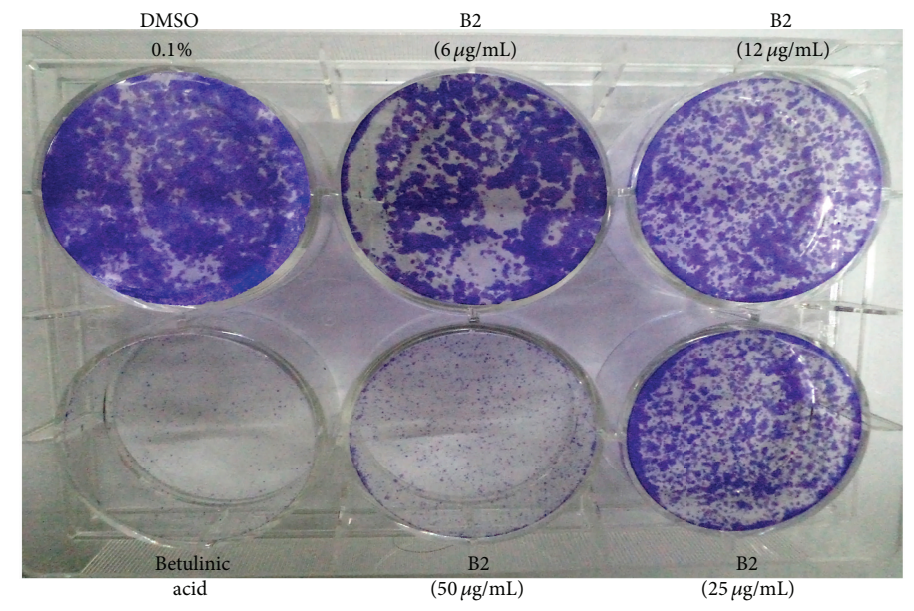

(c)

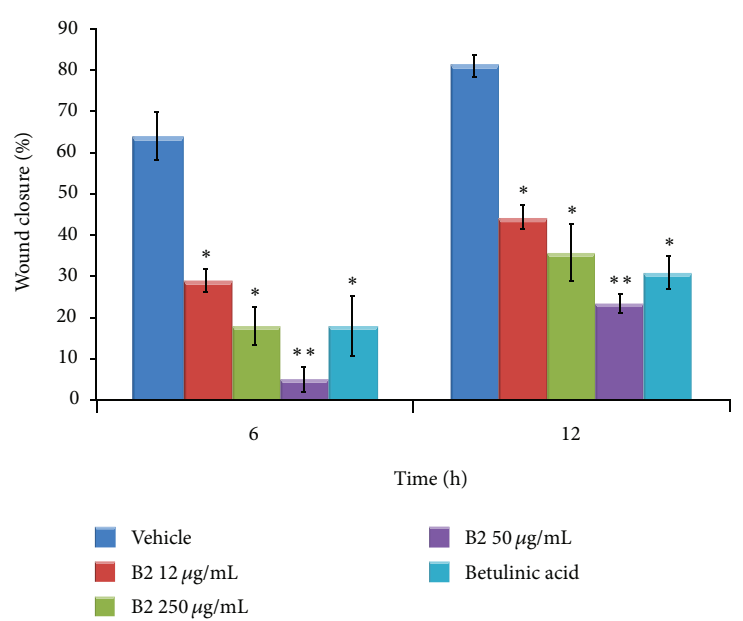

(b)

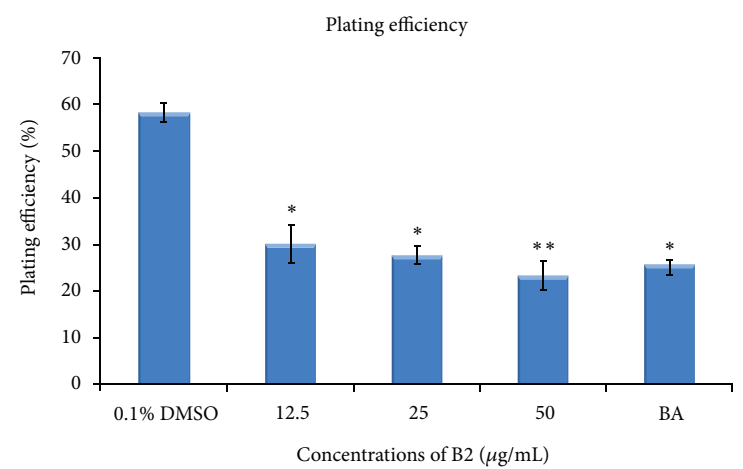

(d)

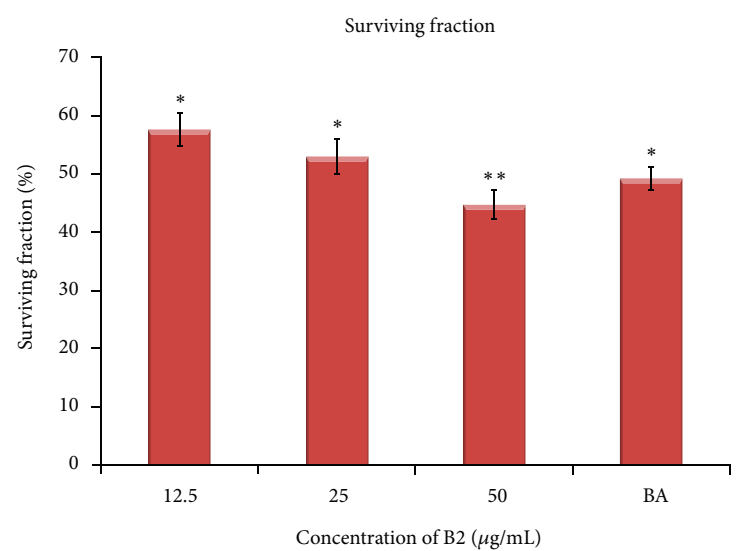

(e)

FIGURE 5: Effect of B2 on migration and colony formation of PC3 cells. For migration assay, a straight scratch wound was created using a 200 $\mu \mathrm{L}$ micropipette tip. The cells were treated with B2 $(12,25$, and $50 \mu \mathrm{g} / \mathrm{mL})$. DMSO $(0.1 \%)$ and betulinic acid were used as negative and positive controls, respectively. The wounds were photographed using EVOS f1 digital microscope at zero, 6 , and $12 \mathrm{~h}$. (a) The images taken form $0.1 \%$ DMSO treated cells showed completely closed wound due to the successful migration of PC3 cells within $12 \mathrm{~h}$, whereas in B2-treated group, the wound remained open even after $12 \mathrm{~h}$ period time. B2 $(12 \mu \mathrm{g} / \mathrm{mL})$ caused significant inhibition of PC3 cell migration at subcytotoxic dose. (b) Graph illustrates the time- and dose-dependent inhibitory effect of B2 on migration of PC3 cells. The distance of cell-free area was measured using Leica Quin software, and the results are presented as mean percentage of migration inhibition \pm SD in comparison with the negative control. (c) Inhibitory effect of B2 on survival of PC3 colonies in colony formation assay. The picture clearly depicts the dosedependent inhibition of PC3 colonies. PC3 cells (500 cells/well) were seeded in 6-well plate and treated with B2 (6, 12, 25, and 50 $\mu \mathrm{g} / \mathrm{mL})$ for $48 \mathrm{~h}$. Betulinic acid $(10 \mu \mathrm{g} / \mathrm{mL})$ and $1 \%$ DMSO were used as positive and negative controls, respectively. The cells were maintained until sufficiently large colonies ( $\geq 50$ cells) were produced for 10 days. The colonies were fixed, stained with $0.2 \%$ crystal violet, and counted under stereomicroscope. (d) Graphical representation depicts percentage of plating efficiency of representative test groups. Plating efficiency was determined by the percent ratio of number of colonies developed to the number of cells initially seeded. (e) Graphical representation illustrates the percentage of surviving fraction obtained after the treatment with B2. The percent surviving fraction of the PC3 colonies was decreased with increasing concentration $\mathrm{B} 2$. All the values are presented as mean $\pm \mathrm{SD}(n=$ either 6 or 10$)$, * represents $P<0.05$, and $* *$ represents $P<0.01$. 
TABLE 5: GC-MS quantitative estimation of phytochemicals in SC- $\mathrm{CO}_{2}$ extract (B2) of O. stamineus.

\begin{tabular}{|c|c|c|c|c|c|}
\hline Peak & $\begin{array}{l}\text { Retention } \\
\text { time (min) }\end{array}$ & Area \% & Phytoconstituents & $\begin{array}{l}\text { Molecular } \\
\text { formula }\end{array}$ & $\begin{array}{c}\text { Molecular } \\
\text { weight }\end{array}$ \\
\hline a & 9.99 & 1.05 & $\begin{array}{l}\text { 1,3-Benzodioxole, 5-[3-acetaminopropyl]-1-methyl-4- } \\
\text { phenyl-3,4-dihydroisoquinoline } \\
\text { myo-1,2,3,4,5,6-hexamethoxycarbonylcyclohexane }\end{array}$ & $\mathrm{C}_{18} \mathrm{H}_{24} \mathrm{O}_{12}$ & 432.375 \\
\hline $\mathrm{b}$ & 11.15 & 1.34 & $\begin{array}{l}\text { 2-Phenanthrenol, } \\
\text { 1,2,3,4,4a,4b,5,6,8a,9,10,10a-dodecahydro-4a,7- } \\
\text { dimethyl-8-[3-cyano-3(trimethylsilyloxy)propyl]-, } \\
\text { acetate }\end{array}$ & $\mathrm{C}_{25} \mathrm{H}_{41} \mathrm{NO}_{3} \mathrm{Si}$ & 431.69 \\
\hline c & 12.19 & 1.24 & $\begin{array}{l}\text { 2-Acetylamino-5-iodo-4-p-tolyl-thi } \\
\text { ophene-3-carboxylic acid ethyl ester }\end{array}$ & $\mathrm{C}_{18} \mathrm{H}_{54} \mathrm{O}_{9} \mathrm{Si}_{9}$ & 667.385 \\
\hline $\mathrm{d}$ & 13.13 & 1.66 & $\begin{array}{l}\text { Benzoic acid, 2,5-bis(trimethylsiloxy)-, trimethylsilyl } \\
\text { ester }\end{array}$ & $\mathrm{C}_{16} \mathrm{H}_{30} \mathrm{O}_{4} \mathrm{Si}_{3}$ & 370.663 \\
\hline $\mathrm{e}$ & 13.98 & 1.46 & Acetamide, N-[(4.alpha.,5.alpha.)-cholestan-4-yl] & $\mathrm{C}_{29} \mathrm{H}_{51} \mathrm{NO}$ & 429.721 \\
\hline $\mathrm{f}$ & 14.78 & 2.35 & Octadecamethyl-cyclononasiloxane & $\mathrm{C}_{18} \mathrm{H}_{54} \mathrm{O}_{9} \mathrm{Si}_{9}$ & 667.385 \\
\hline $\mathrm{g}$ & 15.57 & 2.38 & 1-Monolinoleoylglycerol trimethylsilyl ether & $\mathrm{C}_{27} \mathrm{H}_{54} \mathrm{O}_{4} \mathrm{Si}_{2}$ & 498.886 \\
\hline $\mathrm{h}$ & 16.48 & 6.65 & $\begin{array}{l}\text { 2-Amino-2-oxo-acetic acid, N-[3,4-dimethylphenyl]-, } \\
\text { ethyl ester }\end{array}$ & $\mathrm{C}_{12} \mathrm{H}_{15} \mathrm{NO}_{3}$ & 221.252 \\
\hline $\mathrm{i}$ & 17.60 & 2.15 & 2-Propen-1-one, 1,3-diphenyl & $\mathrm{C}_{15} \mathrm{H}_{12} \mathrm{O}$ & 208.26 \\
\hline $\mathrm{J}$ & 25.33 & 27.84 & Anthracene, 9-(2-propenyl) & $\mathrm{C}_{17} \mathrm{H}_{14}$ & 218.293 \\
\hline $\mathrm{K}$ & 26.39 & 26.86 & $\begin{array}{l}\text { 3,8-Dimethyl-4-(1-methylethylidene)-2,4,6,7,8,8a- } \\
\text { hexahydro-5(1H)-azulenone }\end{array}$ & $\mathrm{C}_{15} \mathrm{H}_{22} \mathrm{O}$ & 218.334 \\
\hline 1 & 27.01 & 4.38 & $\begin{array}{l}\text { Acetic acid (3-hydroxy-7-isopropenyl-1,4a-dimethyl- } \\
\text { 2,3,4,4a,5,6,7,8-octahydronaphthalen-2-yl) } \\
\text { ester }\end{array}$ & $\mathrm{C}_{17} \mathrm{H}_{26} \mathrm{O}_{3}$ & 278.386 \\
\hline
\end{tabular}

a dose-dependent fashion (Figure 6(a)). Nevertheless, the cells from vehicle (0.1\% DMSO) group demonstrated regular architecture of monolayer of PC3 cells with prominent nuclei and intact cell membrane. After $12 \mathrm{hr}$ of $\mathrm{B} 2$ treatment, the condensation of nucleus and dissolution of chromatin can be seen clearly in the cytoplasm. At high concentration of B2 $(40 \mu \mathrm{g} / \mathrm{mL})$, the cells displayed shrunken and crescent shaped nuclei with discrete chromatin bodies which are the characteristic features of advanced stage of apoptosis. The percentage of apoptosis index estimated for negative control was $4 \pm 0.02 \%$ which was significantly increased after the treatment (Figure 6(b)). However, the apoptotic indices for the cells treated with B2 were significantly increased to $19 \pm 1$ and $36 \pm 3 \%$ at 12 and $25 \mu \mathrm{g} / \mathrm{mL}$ concentrations, respectively (Figure 6(b)). Positive control group treated with betulinic acid $(10 \mu \mathrm{g} / \mathrm{mL})$ showed remarkable apoptosis with $43 \%$ apoptotic index.

\subsection{Treatment of B2 Reduced Mitochondrial Membrane Poten-} tial in PC3 Cells. The cells were exposed to rhodamine 123 after $12 \mathrm{hr}$ of treatment and the intensity of rhodamine in the cells was observed (Figure 6(a)). Results of the present study showed an obvious intensification of fluorescence in the untreated cells; however, the signal significantly $(P<$ 0.01 ) dropped in the cells treated with B2, which proposes the damage in mitochondrial membrane and decrease in membrane potential. The dose-dependent effect was evident from the apoptotic indices calculated which were $31 \pm 2$ and $63 \pm 4 \%$ after the treatment with B2 at 12 and $25 \mu \mathrm{g} / \mathrm{mL}$, respectively (Figure 6(b)). The result can be compared to that of betulinic acid $(10 \mu \mathrm{g} / \mathrm{mL})$ which caused $77 \pm 5 \%$ apoptotic index.

3.8. Inhibitory Effect of B2 on Caspases. In the present study, the activity of caspases $3 / 7$, caspase 8 , and caspase 9 was detected in B2-treated PC3 cells by fluorescence microplate reader and fluorescence microscopy using the carboxyfluorescein FLICA apoptosis detection kit. The fluorescent intensity in the photomicrographic images of the PC3 cells (Figure 7(a)) shows the induction of caspase activities. The results of the present study demonstrated that B2 caused significant induction of caspases $3 / 7$ and caspase 9 activities. In addition, considerable activation of caspases 8 was also detected (Figure 7(a)). Figure 7(b) illustrates the quantitative estimation of caspase induction caused by B2 in comparison with positive control, betulinic acid.

3.9. GC-MS Analytical Report. The extract B2 was analysed using GC-MS to specify and quantify the major chemical constituents present in it. Figure 8 depicts the GC-MS of B2. The pie chart in Figure 8 illustrates the composition and proportion of the major chemical constituents in the extract. Detailed characteristics of the peaks identified in the GC-MS (Figure 8) were presented in Table 5. 

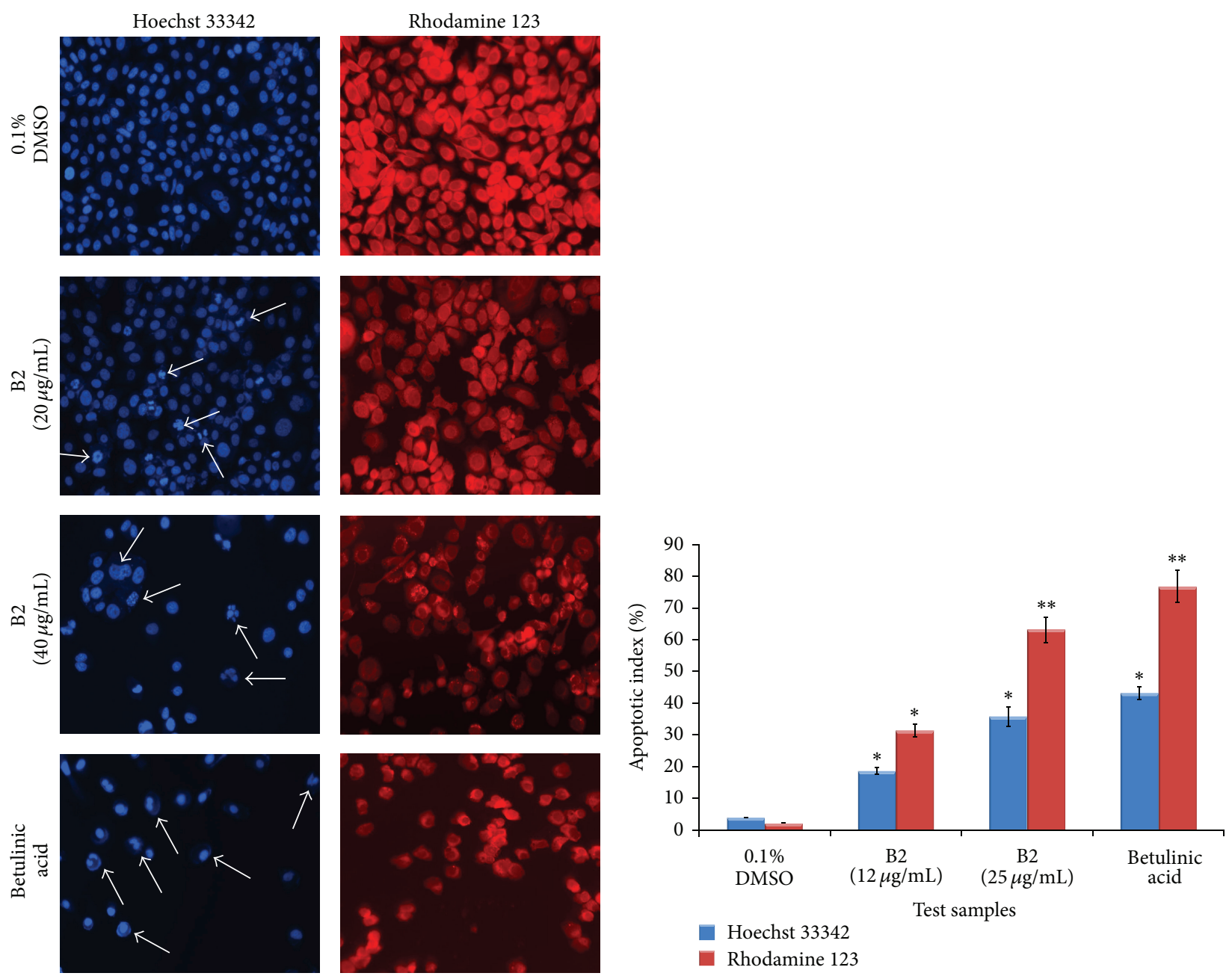

(a)

(b)

Figure 6: Proapoptotic effect of B2 on PC3 cells. The cells were treated with two concentrations (12 and $25 \mu \mathrm{g} / \mathrm{mL})$ of B2 and analysed separately at $12 \mathrm{hr}$. DMSO $(0.1 \%)$ and betulinic acid $(10 \mu \mathrm{g} / \mathrm{mL})$ were used as negative and positive controls, respectively. The cells were fixed in $4 \%$ paraformaldehyde and then stained with either Hoechst stain $33342(1 \mu \mathrm{g} / \mathrm{mL}$ in PBS) or rhodamine $123(5 \mu \mathrm{g} / \mathrm{mL})$ for $20 \mathrm{~min}$. The cellular morphology was photographed at 20x magnification, using EVOS f1 digital microscope (Advanced Microscopy Group, USA). (a) The photomicrographs in the left column depict the images of PC3 cells stained with Hoechst 33258. The cells treated with $0.1 \%$ DMSO (negative control) appeared as confluent monolayer with prominent nuclear and other cellular features. The cells treated with B2 displayed clear characteristic changes of apoptosis. The arrows showed the condensed, fragmented, and crescent shaped nuclei indicating the early phase of apoptosis. In addition, the higher concentration of B2 displayed the chromatin dissolution, breakdown, and fragmentation (arrows), which imply the advanced stage of apoptosis. The results can be compared to that of the standard reference, betulinic acid. The photomicrographs in the right column depict the images of PC3 cells stained with rhodamine 123. The images provide the clear evidence of disruption in the mitochondrial membrane potential caused by B2. The effect in PC3 cells was assessed by visualizing the rhodamine 123 fluorescence signals in the mitochondria. Treatment of cells with B2 showed that the signal decreased proportionally with respect to the decrease of mitochondrial membrane potential. (b) Graphical representation of percentage of apoptotic indices. The apoptotic index for each test group was expressed as a percentage of the ratio of apoptotic cells number to the total cell number in 10 different fields. In Hoechst stain assay, cells with densely blue-colored, condensed, or fragmented nuclei were considered apoptotic. The number of cells with apoptotic morphology was counted in randomly selected fields per well. The apoptotic index was calculated as a ratio of apoptotic cells to the total number of cells and presented as the mean $\pm \operatorname{SD}(n=10) ; *$ represents $P<0.05$ and $* *$ represents $P<0.01$.

\section{Discussion}

Supercritical carbon dioxide $\left(\mathrm{SC}-\mathrm{CO}_{2}\right.$ ) extraction method is an attractive and more advanced technology than the conventional solvent extraction methods. SC- $\mathrm{CO}_{2}$ is nonexplosive, nontoxic, inexpensive, and able to solubilize lipophilic substances $[17,18]$. Carbon dioxide has been shown to ensure minimal alteration of the bioactive compounds and thereby it preserves the native chemical properties of the compounds and thus the curative and functional properties of the compounds will be retained [19]. Therefore, SC- $\mathrm{CO}_{2}$ extraction method gives the extracts with better biological activity than the conventional extractions methods. Moreover, $\mathrm{CO}_{2}$ is gaseous at room temperature and pressure, 

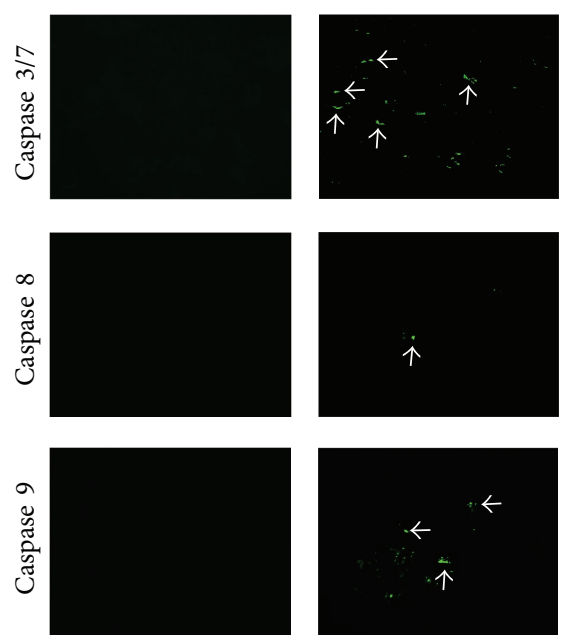

Control

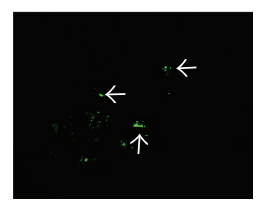

B2
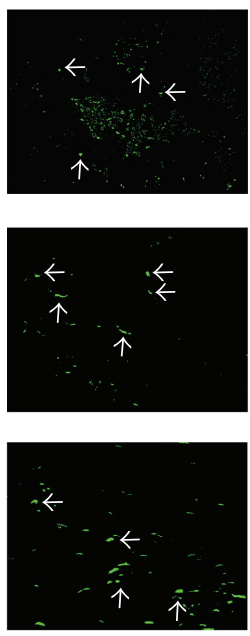

Betulinic acid

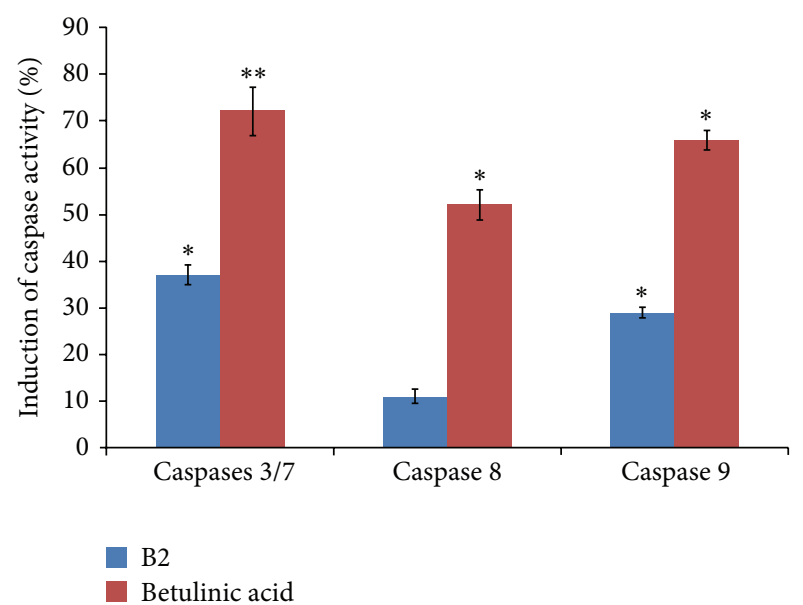

(b)

Figure 7: In caspase assay, PC3 cells $\left(1 \times 10^{5}\right.$ cells $\left./ \mathrm{mL}\right)$ were treated with subtoxic concentration $(10 \mu \mathrm{g} / \mathrm{mL})$ of B2. Betulinic acid $(10 \mu \mathrm{g} / \mathrm{mL})$ and DMSO (0.1\%) were used as positive and negative controls. The cells were labeled with fluorescent FAM-VAD-FMK dye after 8 hours of treatment and incubated for 60 minutes. The media were removed thereafter and the cells were incubated in fresh media for another 60 minutes. The plate was centrifuged at 300 RPM for 5 minutes to include the detached apoptotic cells in the assay. Then the media were replaced by PBS in each well. The fluorescence intensity was recorded at $490 \mathrm{~nm}$ excitation and $520 \mathrm{~nm}$ emission using a fluorescence microplate reader (Multiskan Ascent micro plate reader, Thermolab system 354, Finland). The apoptotic cells were observed under fluorescent microscope at 20x magnification. (a) Photomicrograph of the fluorescence emitting cells. The images were taken by EVOS fluorescence microscope at 20x magnification. (b) Graphical representation depicts the quantitative estimation of percent induction of caspase activity in PC3 cells by B2 and betulinic acid (BA).

which makes the phytochemicals recovery very easy and simple and provides solvent-free extracts. In addition, $\mathrm{CO}_{2}$ is environment-friendly and generally recognized as safe by the Food and Drug Administration and European Food Safety Authority.

In the present study, a full factorial design of $3 \times 3 \times 4$ was carried out with total number of thirty six runs in order to determine the best extraction conditions in terms of extraction yield and antiproliferative and antioxidant properties. The findings of the present study revealed that the percentage yield of the extract was time and pressure dependent and thus the percentage yield increased significantly with increasing pressure and time $(P<0.05)$. In contrast, the percentage yield was noted to be temperature independent. However, the extraction yield was increased with increasing pressure at a fixed extraction temperature. This increment is due to the fact that high pressure increases the density of a supercritical fluid that consequently enhances the solubilizing capability of organic compounds and ultimately helps in dissolving large quantities of the phytoconstituents [20]. On the other hand, temperature poses an opposite effect on the density of $\mathrm{SC}-\mathrm{CO}_{2}$ and therefore the density of $\mathrm{SC}-\mathrm{CO}_{2}$ decreases with increasing extraction temperature at a given operating pressure. This results in reduced solvating power of $\mathrm{CO}_{2}$ which then affects the solubility of the compounds and decreases the extraction efficiency [20]. This could be the reason for the variant effects of temperature on the extraction yield.
Analysis of UV-Vis spectroscopic data indicates a highly polyene nature of the phytoconstituents. Particularly, the extracts A2, B1, B2, B3, C1, C2, and C3 showed clear characteristic peaks for prenyl flavone skeleton compounds such as sinensetin, eupatorin, and tetramethoxyflavone, which are the characteristic markers of O. stamineus. FTIR spectral analysis of the extracts obtained from high temperatures revealed the prominent and broad signals which correspond to the hydroxyl groups. This clearly indicates that the extracts are rich in hydroxyl groups. Usually, polar compounds possess at least one terminal hydroxyl $(-\mathrm{OH})$ group which makes them hydrophilic and therefore less volatile. On the other hand, the extracts obtained at moderate pressure (31.1 MPa) showed IR absorption frequencies corresponding to the olefinic carbon double bonds, which indicates the abundance of unsaturated phytochemicals such as phenolics, flavonoids, and other aromatic compounds.

The findings of the cytotoxic activity showed that, out of 9 extracts studied, B2 (prepared at $31.1 \mathrm{MPa}$ and $60^{\circ} \mathrm{C}$ ) showed selective antiproliferation activity against prostate cancer (PC3) cells. Interestingly, either negligible or insignificant cytotoxic effect of B2 was recorded on other tested cancer cells including the normal CCD-18Co cells. The cytotoxic effect of the B2 against the cancer cells could probably be due to its antioxidant-rich polyphenolic contents. This was further supported by the results of the antioxidant assays. In the present study, the extract B2 demonstrated noticeable scavenging activity against both the tested free radicals, 


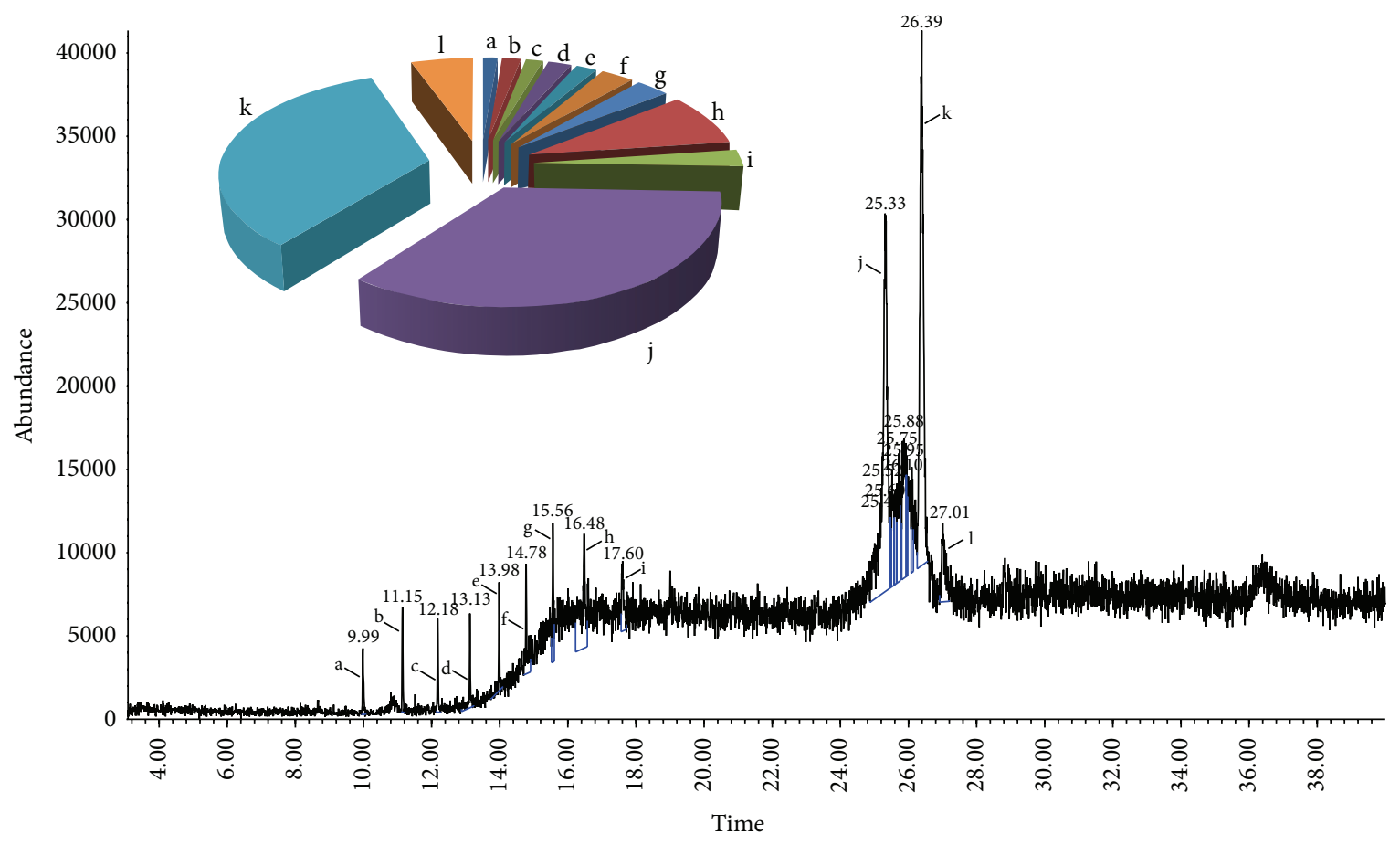

FIGURE 8: Chemical characterization of the extract B2 on mass spectrum of GC-MS was conducted with the help of the Metabolites Spectral Database and NIST (National Institute of Standards and Technology) Library (Ezhilan and Neelamegam, 2012). The identification of the major chemical components was based on similarity index (SI), Wiley 8 computer library. The mass spectrum of the unknown component was compared with the spectrum of the known components stored in the library. The retention time, nomenclature, molecular weight, structure, and composition of the major components were recorded. The pie charts depict the relative chemical compositions of subfractions. The chart illustrates that the dominant peaks of B2 are acetic acid (3-hydroxy-7-isopropenyl-1,4a-dimethyl-octahydronaphthalen-2-yl) ester (27.01\%), dimethyl-4-(1-methylethylidene)-2,4,6,7,8,8a-hexahydro-5(1H)-azulenone (26.86\%), and anthracene, 9-(2-propenyl) (25.33\%). The details of the peaks are given in Table 1 .

ABTS and DPPH. The characteristic chemical markers of $O$. stamineus such as caffeic acid derivatives, polymethoxylated flavonoids, terpenes, and phenolics are well studied antioxidant compounds with potent cytotoxicity [21]. It has been reported that the abundant presence of methoxylated flavonoids (eupatorin and sinensetin) in O. stamineus imparts the cytotoxic property to the extract. Eupatorin was reported as a potent inhibitor for in vitro proliferation of breast cancer cells [22], while sinensetin was reported to inhibit the growth of gastric cancer cells and induces apoptosis [23].

In order to characterise the cytotoxicity induced by B2 in PC3 cells, a series of assays were conducted to get deeper insights into its mode of action. During tumorigenesis, the tumor cells continue their proliferation and migration into the secondary site which leads to metastasis. This is based on the migration and colonization of the tumor cells [24]. B2 suppressed colonization of PC3 cells in a dosedependent manner. It is noteworthy that B2 demonstrated cytotoxic effect at high concentration $(50 \mu \mathrm{g} / \mathrm{mL})$ and caused irreversible damage to the cell integrity; however, at low concentration $(12 \mu \mathrm{g} / \mathrm{mL}) \mathrm{B} 2$ displayed cytostatic effect. The anticlonogenic results indicated that B2 is cytotoxic at high concentration while cytostatic at its low concentration, as evident by decrease of survival fraction. Colonization and migration are the critical processes to promote tumorigenesis and metastasis. In this study, inhibition of migration and colony formation of PC3 cells in vitro by $\mathrm{B} 2$ suggests that the extract could probably inhibit cell metastasis [25]. This indicates that the extract has potential to block the motility of the prostate cancer cells.

Apoptotic cells undergo a series of characteristic morphological and biochemical changes, which usually manifest themselves as nuclear condensation, DNA fragmentation, and chromatin dissolution [13]. In this study, Hoechst-stained images of B2-treated PC3 cells revealed clear proapoptotic signs such as chromatin condensation and dissolution. High concentration of B2 rendered the cells with crescent shaped nuclei, a characteristic feature of advanced stage of apoptosis.

To confirm the apoptosis induced by B2 in PC3 cells involved the loss of mitochondrial membrane potential and integrity in the cells, the effect was assessed by visualizing the uptake of rhodamine 123 by mitochondria. Rhodamine 123 is the lipophilic dye which can be readily absorbed into the mitochondria of live cells [26]. Disturbance in mitochondrial membrane potential $(\Delta \Psi)$ is a clear indication of early apoptotic stage [27]. Uptake of rhodamine 123 by the cells decreases exponentially with decrease of mitochondrial membrane potential, and consequently the intensity of florescent also decreases. The photomicrographic images of B2-treated PC3 cells revealed remarkable reduction in mitochondrial membrane potential, a sign of apoptosis induction. 
The proapoptotic effect of B2 on DNA and mitochondria was further confirmed by measuring the caspases activity in PC3 cells. Caspases are a group of intracellular cysteine proteases that promote apoptosis in the cells. Caspase 9 is an initiator caspase activated by mitochondria via intrinsic pathway. After getting activated, caspase 9 subsequently activates a series of "effector caspases," caspases 3/7, and ultimately the cascade ends with cellular death [28]. However, caspase 8 is an executioner caspase and activated by extrinsic pathway.

The overall result demonstrates that the extract B2 at subcytotoxic concentration $(10 \mu \mathrm{g} / \mathrm{mL})$ caused apoptosis which appears to be chiefly associated with the early activation of caspase 9 through mitochondrial pathway, as confirmed by the loss of mitochondrial membrane potential in Rhodamine 123 assay. The activation of the mitochondrial pathway may in turn induce caspase 8 , eventually resulting in a feedback amplification of caspase 9. Caspases 3 and 7 are the executioner enzymes and their activation results into the nuclear condensation and degradation which further supports the findings of Hoechst stain assay on nuclear condensation and dissolution.

The proapoptotic effect of B2 was further supported by the GC-MS analysis. The major chemical constituents present in the extract were identified using the NIST library. Predominantly, the spectra of B2 showed presence of several biologically dynamic phytoconstituents such as the derivatives of anthracene, hydronaphthalen, and azulenone. Among the identified compounds, anthracene derivatives were reported to possess promising antitumor activity by binding, intercalating, and fragmenting DNA in cancer cells [29-31]. However, the other major compounds identified in B2 such as acetic acid (3-hydroxy-7-isopropenyl-1,4adimethyl-octahydronaphthalen-2-yl) ester and dimethyl-4-(1methylethylidene)-2,4,6,7,8,8a-hexahydro-5(1H)-azulenone were reported as the major chemical composition of the extracts with considerable biological activities including cytotoxic properties $[32,33]$.

\section{Conclusion}

In the present study, a general factorial experiment of type $3 \times 3 \times 4$ was used with total number of thirty-six runs to prepare supercritical $\mathrm{CO}_{2}\left(\mathrm{SC}-\mathrm{CO}_{2}\right)$ extracts of cat's whiskers tea (Orthosiphon stamineus). The $\mathrm{SC}-\mathrm{CO}_{2}$ extract prepared at moderate pressure and temperature $\left(31.1 \mathrm{MPa}\right.$ and $60^{\circ} \mathrm{C}$ ) produced selective cytotoxicity against human prostate cancer (PC3) cells and significant free radical scavenging activity, while being nontoxic to normal cells. Further investigation provided good evidence that the extract displayed proapoptotic, antimetastatic, and anticlonogenic effects in PC3 cells, which could be due to the collective contribution of phytochemicals, particularly, aldehyde, hydrocarbon, ketone, fatty acids, esters, and aromatic sesquiterpenes such as acetic acid (3-hydroxy-7isopropenyl-1,4a-dimethyl-octahydronaphthalen-2-yl) ester, dimethyl-4-(1-methylethylidene)-2,4,6,7,8,8a-hexahydro-5
(1H)-azulenone, anthracene, 9-(2-propenyl), 2-propen-1one, 1,3-diphenyl, and 2-amino-2-oxo-acetic acid N-(3,4dimethylphenyl) ethyl ester. Thus, the bioactive extract of cat's whiskers tea prepared using an inexpensive and environment-friendly supercritical $\mathrm{CO}_{2}$ could be a valuable bioresource with anticancer potential against prostate malignancy.

\section{Conflict of Interests}

The authors declare that there is no conflict of interests regarding the publication of this paper.

\section{Acknowledgments}

The authors gratefully acknowledge the financial support of the Universiti Sains Malaysia, under grant no. 1001/ PPSK/8120243, RU, and Malaysian Ministry of Higher Education, grant no. FRGS: 203/PFARMASI/671196. The authors are also thankful to the MAKNA Research Grant no. 304/PFARMASI/650547/M122. The authors also acknowledge the Ministry of Agriculture, Malaysia, under NRGS grant no. 304/PFARMASI/650583/K123 and the Research University Team (RUT) Grant no. 1001/PFARMASI/851001.

\section{References}

[1] P. T. Eisai, Medicinal Herb Index in Indonesia, P. T. Eisai, Jakarta, Indonesia, 1995.

[2] C.-L. Hsu, B. O.-H. Hong, Y. S. Yu, and G.-C. Yen, "Antioxidant and Anti-Inflammatory effects of Orthosiphon aristatus and its bioactive compounds," Journal of Agricultural and Food Chemistry, vol. 58, no. 4, pp. 2150-2156, 2010.

[3] H. Muhammad, M. R. Gomes-Carneiro, K. S. Poa et al., "Evaluation of the genotoxicity of Orthosiphon stamineus aqueous extract," Journal of Ethnopharmacology, vol. 133, no. 2, pp. 647653, 2011.

[4] M. B. K. Ahamed, A. F. A. Aisha, Z. D. Nassar et al., "Cat's whiskers tea (Orthosiphon stamineus) extract inhibits growth of colon tumor in nude mice and angiogenesis in endothelial cells via suppressing VEGFR phosphorylation," Nutrition and Cancer, vol. 64, no. 1, pp. 89-99, 2012.

[5] F. S. R. Al-Suede, F. Elham, B. Mohamed, Z. Ismail, A. S. A. Majid, and A. M. S. Abdul Majid, "Marked antitumor activity of cat's whiskers tea (Orthosiphon stamineus) extract in orthotopic model of human colon tumor in nude mice," Journal of Biochemical Technology, vol. 3, no. 5, pp. S170-S176, 2012.

[6] S. Scalia, L. Giuffreda, and P. Pallado, "Analytical and preparative supercritical fluid extraction of Chamomile flowers and its comparison with conventional methods," Journal of Pharmaceutical and Biomedical Analysis, vol. 21, no. 3, pp. 549-558, 1999.

[7] E. Reverchon, "Supercritical fluid extraction and fractionation of essential oils and related products," The Journal of Supercritical Fluids, vol. 10, no. 1, pp. 1-37, 1997.

[8] C. K. Karale, P. J. Dere, B. S. Honde, K. Sachin, and P. K. Amol, "A overview of supercritical fluid extraction for herbal drugs," Pharmacologyonline, vol. 2, no. 2011, pp. 575-596, 2011. 
[9] M. B. Khadeer Ahamed, V. Krishna, and C. J. Dandin, "In vitro antioxidant and in vivo prophylactic effects of two $\gamma$ lactones isolated from Grewia tiliaefolia against hepatotoxicity in carbon tetrachloride intoxicated rats," European Journal of Pharmacology, vol. 631, no. 1-3, pp. 42-52, 2010.

[10] S. F. Jafari, M. B. K. Ahamed, M. A. Iqbal et al., "Increased aqueous solubility and proapoptotic activity of potassium koetjapate against human colorectal cancer cells," Journal of Pharmacy \& Pharmacology, 2014.

[11] O. S. A. Al-Salahi, C. Kit-Lam, A. M. S. A. Majid et al., "Antiangiogenic quassinoid-rich fraction from Eurycoma longifolia modulates endothelial cell function," Microvascular Research, vol. 90, pp. 30-39, 2013.

[12] H. M. Baharetha, Z. D. Nassar, A. F. Aisha et al., "Proapoptotic and antimetastatic properties of supercritical $\mathrm{CO}_{2}$ extract of Nigella sativa Linn. against breast cancer cells," Journal of Medicinal Food, vol. 16, no. 12, pp. 1121-1130, 2013.

[13] Z. D. Nassar, A. F. Aisha, N. Idris et al., "Koetjapic acid, a natural triterpenoid, induces apoptosis in colon cancer cells," Oncology Reports, vol. 27, no. 3, pp. 727-733, 2012.

[14] L. E. Ahmed Hassan, M. B. Khadeer Ahamed, A. S. Abdul Majid et al., "Crystal structure elucidation and anticancer studies of (-)-pseudosemiglabrin: a flavanone isolated from the aerial parts of Tephrosia apollinea," PLoS ONE, vol. 9, no. 3, Article ID e90806, 2014.

[15] N. S. Yaacob, N. Hamzah, N. N. Nik Mohamed Kamal et al., "Anticancer activity of a sub-fraction of dichloromethane extract of Strobilanthes crispus on human breast and prostate cancer cells in vitro," BMC Complementary and Alternative Medicine, vol. 10, no. 1, p. 42, 2010.

[16] D. L. Pavia, G. M. Lampman, G. S. Kriz, and R. G. Engel, A Small Scale Approach to Organic Laboratory Techniques, Brooks/Cole, Belmont, Calif, USA, 2009.

[17] L. Wang and C. L. Weller, "Recent advances in extraction of nutraceuticals from plants," Trends in Food Science and Technology, vol. 17, no. 6, pp. 300-312, 2006.

[18] F. Sahena, I. S. M. Zaidul, S. Jinap et al., "Application of supercritical $\mathrm{CO}_{2}$ in lipid extraction: a review," Journal of Food Engineering, vol. 95, no. 2, pp. 240-253, 2009.

[19] S. Cavero, M. R. García-Risco, F. R. Marín et al., "Supercritical fluid extraction of antioxidant compounds from oregano. Chemical and functional characterization via LC-MS and in vitro assays," The Journal of Supercritical Fluids, vol. 38, no. 1, pp. 62-69, 2006.

[20] S. M. Pourmortazavi and S. S. Hajimirsadeghi, "Supercritical fluid extraction in plant essential and volatile oil analysis," Journal of Chromatography A, vol. 1163, no. 1-2, pp. 2-24, 2007.

[21] N.-K. Olah, L. Radu, C. Mogoşan, D. Hanganu, and S. Gocan, "Phytochemical and pharmacological studies on Orthosiphon stamineus Benth. (Lamiaceae) hydroalcoholic extracts," Journal of Pharmaceutical and Biomedical Analysis, vol. 33, no. 1, pp.117123, 2003.

[22] V. Androutsopoulos, R. R. J. Arroo, J. F. Hall, S. Surichan, and G. A. Potter, "Antiproliferative and cytostatic effects of the natural product eupatorin on MDA-MB-468 human breast cancer cells due to CYP1-mediated metabolism," Breast Cancer Research, vol. 10, no. 3, article R39, 2008.

[23] Y. Dong, G. Ji, A. Cao et al., "Effects of sinensetin on proliferation and apoptosis of human gastric cancer AGS cells," Zhongguo Zhongyao Zazhi, vol. 36, no. 6, pp. 790-794, 2011.

[24] M. Bockhorn, R. K. Jain, and L. L. Munn, "Active versus passive mechanisms in metastasis: do cancer cells crawl into vessels, or are they pushed?" The Lancet Oncology, vol. 8, no. 5, pp. 444448, 2007.

[25] A. Valster, N. L. Tran, M. Nakada, M. E. Berens, A. Y. Chan, and M. Symons, "Cell migration and invasion assays," Methods, vol. 37, no. 2, pp. 208-215, 2005.

[26] M. Castedo, K. Ferri, T. Roumier, D. Métivier, N. Zamzami, and G. Kroemer, "Quantitation of mitochondrial alterations associated with apoptosis," Journal of Immunological Methods, vol. 265, no. 1-2, pp. 39-47, 2002.

[27] J. Skommer, D. Wlodkowic, and A. Deptala, "Larger than life: mitochondria and the Bcl-2 family," Leukemia Research, vol. 31, no. 3, pp. 277-286, 2007.

[28] M. A. McDonnell, D. Wang, S. M. Khan, M. G. Vander Heiden, and A. Kelekar, "Caspase-9 is activated in a cytochrome cindependent manner early during $\mathrm{TNF} \alpha$-induced apoptosis in murine cells," Cell Death and Differentiation, vol. 10, no. 9, pp. 1005-1015, 2003.

[29] R. T. Dorr, J. D. Liddil, S. M. Sami, W. Remers, E. M. Hersh, and D. S. Alberts, "Preclinical antitumor activity of the azonafide series of anthracene-based DNA intercalators," Anti-Cancer Drugs, vol. 12, no. 3, pp. 213-220, 2001.

[30] M. Agbandje, T. C. Jenkins, R. McKenna, A. P. Reszka, and S. Neidle, "Anthracene-9,10-diones as potential anticancer agents. Synthesis, DNA- binding, and biological studies on a series of 2,6-disubstituted derivatives," Journal of Medicinal Chemistry, vol. 35, no. 8, pp. 1418-1429, 1992.

[31] G. T. Bowden, R. Roberts, D. S. Alberts, Y. M. Peng, and D. Garcia, "Comparative molecular pharmacology in leukemic L1210 cells of the anthracene anticancer drugs mitoxantrone and bisantrene," Cancer Research, vol. 45, no. 10, pp. 4915-4920, 1985.

[32] H. Chen, Y. Yang, J. Xue, J. Wei, Z. Zhang, and H. Chen, "Comparison of compositions and antimicrobial activities of essential oils from chemically stimulated agarwood, wild agarwood and healthy Aquilaria sinensis (Lour.) Gilg trees," Molecules, vol. 16, no. 6, pp. 4884-4896, 2011.

[33] M. S. Muthuraman, S. Mani, U. Thangaraj, and A. Sivasubramanian, "In vitro cytotoxicity and molecular docking studies on Acanthophora spicifera," Der Pharma Chemica, vol. 6, no. 1, pp. 411-417, 2014. 


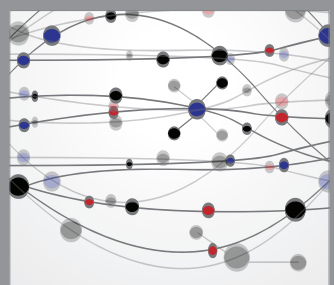

The Scientific World Journal
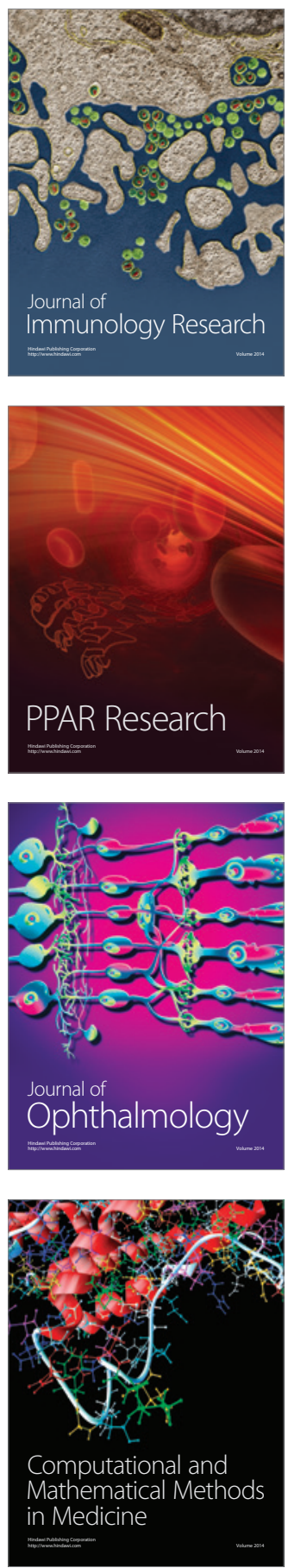

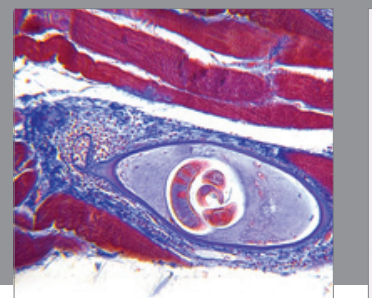

Gastroenterology

Research and Practice
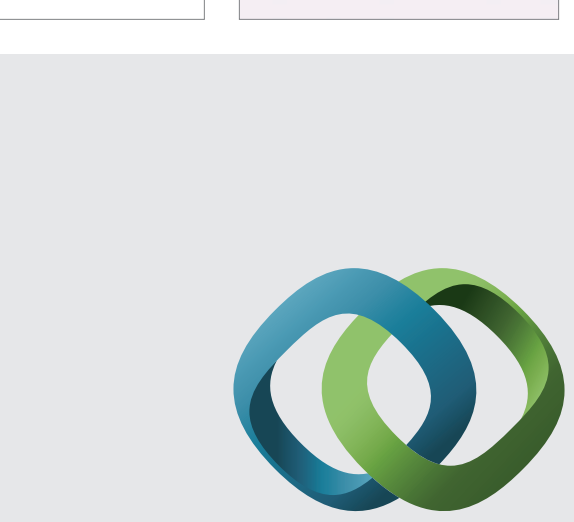

\section{Hindawi}

Submit your manuscripts at

http://www.hindawi.com
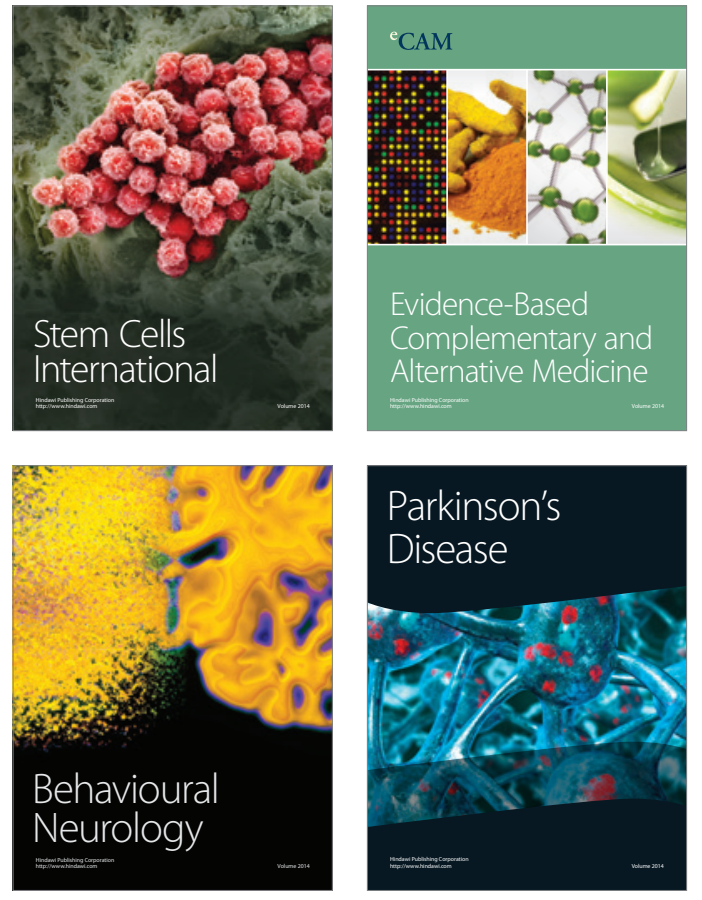
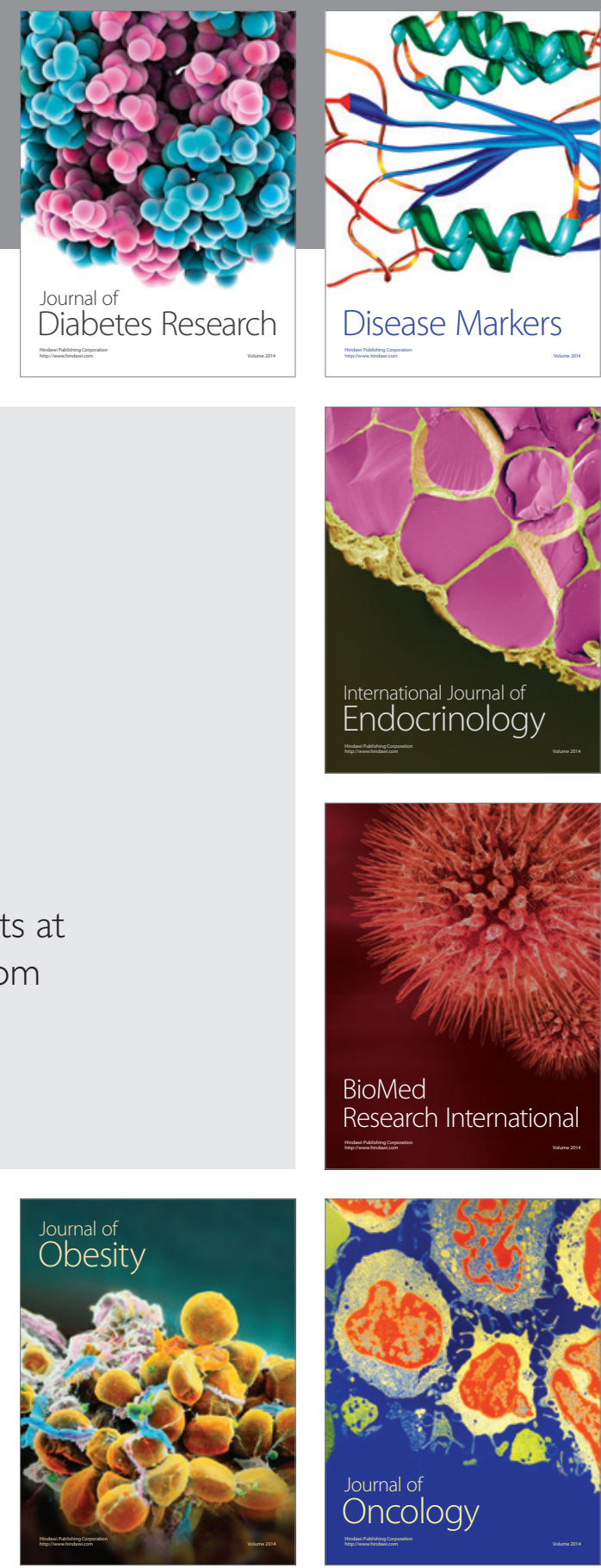

Disease Markers
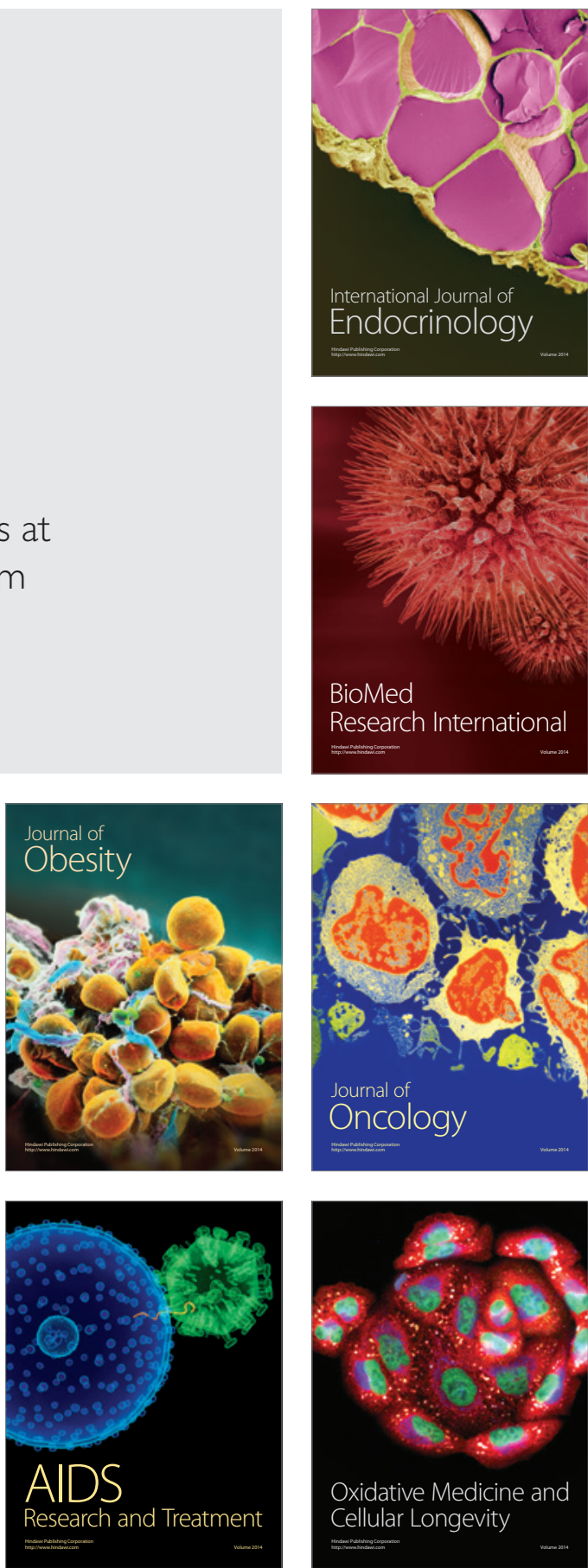